\title{
Vindicación del humanismo (XV Conferencias Aranguren)
}

\author{
AMELIA VALCÁRCEL \\ UNED, Madrid
}

\begin{abstract}
Resumen. La Edad Global nos exige repensar el humanismo. Primero como raíz de la Ilustración; después como matriz del universalismo, por último en su presentación feminista. El humanismo es algo más que una vaga disposición benévola hacia los demás: es el universalismo, el fundamento del conocimiento y de la ética, que nos acompaña en los tres últimos y decisivos siglos. La humanidad requiere para ser una, acabar con la dinámica más antigua, nosotros y ellos, e inventar el universalismo. Éste es probablemente una de las más difíciles invenciones humanas, lleva varios ensayos, duros, y su éxito todavía no está asegurado. El humanismo es la posibilidad de reunir ética y política y ahora juega en el complejo terreno del mundo global.
\end{abstract}

Palabras clave: Ética, Política moral, Humanismo, Derechos humanos, feminismo, relativismo, Globalización, Ilustración.
Abstract. The Global Age demands to us rethinking the humanistic tradition. First, because it is the origin of Enlightenment; second, because its universalistic frame; al least in its feministic presentation. Humanism is not a friendly and vagarious disposition to the others: it is the universalism, the foundation of knowledge and ethics, and walk with us through the three decisive last centuries. But the mankind requires, to be one, finish with the most old group dynamics, we and the others. The invention of universalism is one of the most difficult human challenges; we try to do many times, and we know it is hard: the success is still not assured. Now works in the complex arena of de Global World.

Key words: Ethics, Moral politics, Humanism, human rights, feminism, relativism, Global Age, Enlightenment.

\section{El tejido del mundo}

Intentaré exponer, en esta primera aproximación, el pasado del asunto que me ocupa. Y lo haré por referencia a tres bloques de sentido y un breve epílogo en los cuales el término humanismo ocurre. El primero será el renacentista, el segundo el dialelo entre humanidades y ciencias y, por último, el debate del humanismo en la segunda mitad del siglo XX.

Nuestro mundo está inmerso en un acelerado proceso de globalización. El planeta se encuentra ahora envuelto por un velo de mensajes, datos y palabras; lo cubre casi por completo una red invisible de comunicación en tiempo 
real. Y a la vez nuestra capacidad física de trasladarnos en él se ha hecho tan amplia que podemos, verdadera y significativamente, recorrerlo entero en pocos días. Los asombrosos avances en telecomunicaciones y transportes han cambiado la percepción que tenemos de él. Todos estos procesos comunicativos lo han hecho más pequeño. Todos pensamos ahora que la tierra es un planeta pequeño. Nuestro mundo apenas tiene o ya no tiene zonas desconocidas $o$ inaccesibles. Y ya no es, en ese sentido, misterioso.

Este actual estado de cosas fue preparado por las ideas previas correspondientes y las técnicas que tales ideas hicieron verosímiles. Me refiero al modo, manera y momento en que la humanidad se puso en el camino de ese cambio que vivimos.

\section{Humanismo y Renacimiento}

Para trocar la escala del mundo, la escala humana previamente cambió. Conocemos el inicio de ese proceso con el nombre de humanismo. «Humanismo» es un término que nos viene de cerca ${ }^{1}$. Comenzó a utilizarse para significar la nueva cultura a la que el mundo medieval se abrió. Entonces, durante su largo Renacimiento ${ }^{2}$, Europa se repobló, se urbanizó, superó graves amenazas, reconstruyó las antiquísimas rutas comerciales. Inició una bullidora exploración de sus civilizaciones coterráneas. Y a la vez se volvió hacia su pasado. Abrió una cultura basada en la recuperación del mundo clásico ${ }^{3}$. La cultura humanista fue en un principio erudición de los sabios urbanos por oposición al canon de cultura gestado por el monacato. Así, entendemos por Humanismo ${ }^{4}$ lo contrario de escolástica y de ahí nos viene ese nombre con sus resonancias abiertas. Tan cargado estuvo ese término, humaniora, en origen que aún seis siglos después suena a libertad en nuestros oídos. El huma-

1 Se atribuye su invención, en su sentido histórico, a Niethammer, el amigo y protector de Hegel, en el curso de un debate sobre el lugar que debían ocupar las lenguas clásicas en la educación secundaria; Bullock, A. La tradición humanista en Occidente (1985), Alianza, Madrid, 1989.

${ }^{2}$ El renacimiento temprano tiene una versión sobre todo italiana cuyo mejor estudioso ha sido E. Garin en La revolución cultural del Renacimiento (1967), Critica, Barcelona, 1981, o El Renacimiento italiano (1980), Ariel, Barcelona, 1986. Garin resalta justamente el renacimiento como «tiempo largo» y su carácter LUMINOSO, ilustrado.

${ }^{3}$ Una que sólo tuvo éxito estético, porque el debate religioso copó el panorama de la acción y del lenguaje compartido, como ya lo anunciaba la temprana postura de Savonarola. Sobre este asunto, el distinto Renacimiento del Norte y del Sur, es también muy útil la obra de Bullock que se acaba de citar.

${ }^{4}$ Los studia humanitatis han sido puestos en su correcta perspectiva también por F. Rico en El sueño del humanismo: de Petrarca a Erasmo, Alianza, Madrid, 1993 y en su trabajo más volcado en el renacimiento humanista español El pequeño mundo del hombre, Alianza, Madrid, edición aumentada, 1986. Con similar óptica, aunque incluyendo las referencias portuguesas y algunas americanas, M. Batllori Humanismo y Renacimiento, Ariel, 1987, reeditado en Círculo de Lectores, 1995. 
nismo renacentista fue toda una nueva disposición hacia el saber, la belleza y el mundo. Su enunciado de sistema fue «el hombre es la medida de todas las cosas»; este viejo aforismo griego, atribuido a Protágoras, recuperado por la cultura secular renacentista, vino a expresar las ansias europeas de recrear la noble edad antigua ${ }^{5}$. Los humanistas daban voz y precisión a ese deseo: nueva literatura, uso de las lenguas romances, ironía, exaltación de pasiones poco permitidas, verdad, salud, desafíos. El primer humanismo sobre todo renunció a pensar que la verdadera vida humana se jugaba y permanecía fuera del ámbito de la vida mortal ${ }^{6}$. El elogio de la vida y lo que tiene de bueno y amable llena las páginas de la literatura humanista. Y con él, el de la elegancia en la lengua, las maneras, los sentimientos, en pocas palabras, en verdad en una que la propia época revalidó, el ideal de «cortesanía» que se gesta y madura durante dos siglos y cuyo mejor resumen es un renacentista, Castiglione ${ }^{7}$. Pero ese Renacimiento produjo una cultura elitista que no pudo dejar de ser$10{ }^{8}$. La calidad de la obra humanista era extraordinaria, pero la cantidad que la respaldaba o podía llegar a hacerlo resultó insuficiente. Esta dinámica nunca debe ser menospreciada.

Desde ese cambio de actitud que introduce el primitivo humanismo hasta nosotros hay cinco siglos de avances y vueltas atrás. También desde esa fecha nos vienen los más significativos cambios de mundo: el agrandamiento del planeta con los descubrimientos, la consolidación de la geografía como ciencia principalísima, la refundación política de las sociedades humanas por obra de las declaraciones ilustradas, los saltos enormes en innovaciones técnicas. El primer humanismo acumuló el monto de confianza que hizo posible el cambio de paradigma sociomoral: de las sociedades monásticas a la confianza en los logros de la inteligencia y la voluntad humanas, al interés y la admiración por ese producto inacabado que es el ser humano, por usar la manera en que Pico de la Mirandola lo describió. Pero si contemplamos más de cerca el humanismo renacentista nos sorprenderá su profundo elitismo. Se

\footnotetext{
5 Ese motivo está particularmente vivo en el Renacimiento del Sur, sobre todo en Italia, y aparece constantemente desde Petrarca a Piero de la Francesca, da Vinci, Ghiberti, Cellini, Bembo, en fin, todos los artistas y tratadistas, sin olvidar a los neoplatónicos italianos, Ficino, Campanella, etc.

${ }^{6}$ Los contertulios y contertulias del Decamerón, sin dejar de ser creyentes, prefieren retirarse a una villa que permanecer en la ciudad apestada asistiendo a responsos, penitencias y peticiones de clemencia a la divinidad. Cosa sabida es que hay que morir, pero nada obliga a desearlo.

${ }^{7}$ El Cortesano, en efecto, es la obra que mejor nos resume toda esta nueva actitud vital. El ideal que presenta es bello, noble y elegante, «ingenio, hermosura de rostro, y buena disposición de cuerpo, y aquella gracia que le haga luego a la primera vista agradable a todo el mundo»; op. cit., ed. esp. Orbis, 1985, pp. 44 y ss. Sobre el nexo de unión entre cortesanía y ciudadanía el clásico de N. Elias El proceso de civilización (1977) FCE, 1987.

${ }^{8}$ En sus partes corrientes, de hecho se convertía en la vieja gramática, F. Rico, El sueño del humanismo, p. 77.
} 
basa mucho más en una estética que en una ética. Se es humanista porque la humanidad agrada, satisface, enorgullece; pero no toda. Sólo la de aquellos que son nobles, vigorosos de alma, audaces, amantes de lo bello. Si además existe una humanidad doliente ésa no merece atención y sí, a veces, burla. Es su problema si no están a la altura ${ }^{9}$. El gran Renacimiento es poco o nada compasivo. La humanidad estimable se retrata en las grandes pinturas en las que los desheredados no cuentan. En el viejo humanismo hay giro antropocéntrico por oposición a teocentrismo; cultura secular frente a mundo clerical; empero, y quizá por ello, su marcado elitismo. Esa cultura no fue capaz de percibir lo que la Florencia de Savonarola claramente anunciaba: que era el lenguaje y la visión religiosa del mundo lo que seguía siendo común y compartido en Europa y también lo que acabaría por llenar las mentes y las páginas de la inmediata Historia Europea. Los textos y las palabras tenidas en común serían los evangelios que un monje agustino, aterrado por el neopaganismo italiano ${ }^{10}$, traduciría a las lenguas bárbaras.

La gran cultura humanista tuvo que someterse y ceder ante la Reforma. El humanismo clasicista cayó ante la vigorosa reforma del cristianismo y los terremotos políticos que provocó. Pervivió su estética, pero naufragó su aliento ético señorial. Sólo algunos lo conservaron, en modo irónico y escéptico, como Montaigne. No estaba hecho para las gentes del común. El humanismo que pervivió en las artes y las bellas letras se tornó pesimista sobre la naturaleza humana; se revolvió, silenciosamente, contra el credo de la universal salvación: cada uno es como es: Montaigne escribe que los pobres en invierno, pese a caminar prácticamente desnudos, no pasan frío, como tampoco saben apreciar los ruines cualquier tipo de delicadeza ${ }^{11}$. La humanidad no es única. Los descubrimientos la están mostrando como múltiple, ahora diríamos multicultural; y ya nadie realizará las ecuaciones de Vasco de Gama, que llega a adorar a la Virgen María en un templo Hindú o la de Magallanes que planta la cruz donde va e insta a todos los reyes de Indonesia y Pacífico a abandonar

9 Me refiero a ese descuido por el prójimo que comparten Montaigne y Rabelais, el primero en sus Ensayos y el segundo en Gargantúa y Pantagruel. Escribe el primero: «No recuerdo quién preguntaba a un mendigo, a quien veía en camisa, en pleno invierno, tan alegre como cualquiera otro que se tapa hasta las orejas, cómo podía vivir con tan ligero traje "Vos, Señor, respondió el interpelado, lleváis la faz descubierta; pues bien, suponed que yo soy todo faz"»; y, poco después apostilla: "Yo no puedo ir desabotonado y con los vestidos sueltos, los jornaleros de mi vecindad se violentarían si lo fueran». En conclusión, «hay mayor diferencia entre tal y tal hombre que entre tal y tal animal... y existen tantos grados en el espíritu humanos como brazas de la tierra al cielo». Op. cit., Aguilar, 1962, tomo I, pp. 233 y 270.

10 J. Brotton El bazar del Renacimiento, Paidós, Barcelona, 2003, p. 109.

11 En su diario de viaje por Italia Montaigne se detiene en Roma para tratar con el colegio Apostólico que no le censuren sus escritos; lo logra. Él mismo apunta que se está entre iguales. Las guerras iniciadas por la Reforma no le interesan, son asuntos para otros, o de poder, geopolíticos, maquiavelianos. La belleza es otra cosa y para los pocos. Incluso pide ser ciudadano romano, simplemente por gusto. Diario de viaje a Italia por Suiza y Alemania, Península, 1986, p. 113. 
sus costumbres ancestrales ${ }^{12}$. Vamos sabiendo cosas. El pirronismo político y moral es una de ellas, muy importante. Comerciar, si se puede; intervenir, lo menos. Los imperios ilustrados ya lo saben: Robinson está solo ${ }^{13}$. Sacar todas las consecuencias de esto, de la multiculturalidad y la difícil unidad humana, abrirlas, desplegarlas, llevará largo tiempo. Es tarea que a mi entender continúa.

\section{Las dos culturas}

Hay un segundo sentido que guarda el término humanismo, que ya no es parte de la oposición cultura clerical o cultura secular, sino el vinculado con otra oposición más reciente, la que pone a las letras frente a las ciencias. Y éste es bastante actual, aunque la oposición venga también de antiguo. A partir del Renacimiento y sobre todo del Barroco la marcha de la historia se hace rápida y nuestro poder técnico comienza a azuzarla. Y entonces comienza a presentarse la fisura entre las humanidades y las ciencias. Lo que llamamos humanismo, su constelación semántica, significará y dará nombre a los estudios de humanidades, historia y bellas letras, mientras que ciencias y técnicas comienzan a desgajarse de él.

Estamos acostumbrados a unir las nociones de utilidad y eficacia, dos de las más relevantes del tiempo presente, con los conocimientos tecnificados. En el progresivo separarse de los saberes científicos y los humanísticos, las humanidades parecen despertar menos respeto y apoyo general que en el pasado, mientras que las ciencias, acompañadas de las técnicas, se avalan por sí solas. La disputa por el territorio y el aprecio de las que Snow llamó «las dos culturas» tiene en el inicio del tercer milenio un gran relieve, que no se limita a lizas ya conocidas entre sectores profesionales, sino que compromete la escala y contenidos de valor desde los que se afronta el proceso de mundialización. El «debate de las humanidades», que de cuando en cuando se intenta abrir, procura sentar las bases de acuerdo con que se aborda ese reto, no meramente salvar la indiscutible competencia de disciplinas como la historia, las letras, las artes o la filosofía. Sus estudios se abandonan ${ }^{14}$ a la vez que se especializan en grado sumo ${ }^{15}$. Las humanidades, en resumen, se sienten des-

12 Pigafetta, «Noticias del nuevo mundo», en La primera vuelta al mundo, Miraguano Editores, Madrid, 2003, pp. 236, 249, 275.

13 «Las costumbres comerciales extrañas no se toleraban en los mercados que eran comunes, pero las leyes de familia, el "derecho privado" eran competencia plena de las autoridades religiosas tradicionales o de los ancianos (varones)», M. Walzer, Tratado sobre la tolerancia, Paidós, Barcelona, 1998.

14 Europa necesitará dentro de una década docentes de humanidades que no podrá suministrar; tenemos el avance en la situación de Holanda en la actualidad, pero basta en el caso español con proyectar a futuro los datos de las facultades humanísticas.

15 Son los «libros para tres mil bibliotecas» de los que habla E. W. Said «antagonistas, públicos, seguidores y continuidad» en La postmodernidad, Kairós, Barcelona, 1985, pp. 199 y 
colgadas del conjunto decisivo del saber. Pertenecen al mundo de las élites antiguas, un mundo ya transcurrido.

Un buen filósofo del siglo Xx, Snow, afirmó que ese era uno de nuestros problemas: que el conjunto de los saberes no era un conjunto, sino dos culturas que no se conocían ni se reconocían entre sí. «Los no científicos tienen la impresión muy arraigada de que los científicos son optimistas por pura superficialidad, por ignorancia de la condición del hombre. Por otra parte, los científicos creen que los intelectuales literarios carecen por completo de visión anticipadora, que viven singularmente desentendidos de sus hermanos los hombres» ${ }^{16}$. Snow achaca a las letras la peor parte: «si los científicos llevan el futuro en la masa de la sangre, entonces la cultura tradicional responde con el deseo de que el futuro no exista. Y es la cultura tradicional, en una medida muy poco menguada por la emergencia de la científica, la que dirige el mundo occidental» ${ }^{17}$. Estos reproches, algo saintsimonianos, se dirigen contra los utopistas negativos, pero también contra quienes no quieren entender que «la revolución científica es el único método merced al cual la mayor parte de los humanos puede obtener los bienes básicos, años de vida, liberación del hambre, supervivencia de los hijos): esos bienes básicos que nosotros damos por descontados pero que disfrutamos en realidad gracias a que tuvimos nuestra revolución científica no hace todavía tanto tiempo. No entender bien esta situación, es tanto como no comprender el presente y el futuro» ${ }^{18}$. La ciencia es la humanista, mientras que, según Snow, las viejas humanidades se resisten, en parte por snobismo, a abandonar el mito de la sociedad preindustrial. «Llevamos tres o cuatro generaciones viviendo en un proceso de cambio rápido. Ahora el cambio se está acelerando. Y todavía va a acelerarse mucho más» avisa Snow; por lo tanto es peligroso que existan dos culturas que no lleguen a entenderse, porque es la ciencia quien actualmente determina si hemos de vivir o perecer. Las humanidades no nos están proveyendo de cualidades humanas, de la sensatez necesaria para manejar el proceso.

\section{Las otras invenciones}

Una queja complementaria de ésta, viene de más antiguo. Ya Rousseau en el siglo XVIII había asegurado que el progreso en ciencias y técnicas no suponía de ningún modo que existiera un progreso paralelo en moral. Es más, aseveró que cuanto más crecían nuestras habilidades en ciencias y artes más se echaba de ver que en moral caminábamos todavía en el paisaje más primitivo ${ }^{19}$. El

ss. o la guetización de la gran cultura de los que avisaba Eco hace ya décadas en un artículo que se hizo célebre: Eco, U. «Entramos en la Edad Media», Triunfo, 4-3-1972.

16 Las dos culturas (1959), Alianza, Madrid, 1977, p. 15.

17 Ibidem, p. 21

18 Ibidem, p. 90.

19 En su Discurso para la Academia de Dijon que lo elevó a la competencia intelectual dentro del círculo enciclopedista, por más que Rousseau no compartiera precisamente la con- 
humanismo no estaba ganando posiciones a la par del desarrollo de los productos de la inteligencia humana. Está claro que lo que deploran algunos ilustrados, además de Rousseau, es esa falta de humanidad en el sentido moral en la que los renacentistas no habían reparado. Desde la Ilustración se oye decir cada vez más, y muchas veces con razón, que tenemos una enorme capacidad de innovación y adelanto técnico, pero que no parece que nuestra capacidad de innovación moral siga el mismo acelerado ritmo. Habría ejemplos de sobra para probarlo. Nuestro complejo mundo sueña con la técnica que evite el sufrimiento, pero las que tiene las usa para aumentar el dolor de algunos o se desinteresa del dolor de los que no pueden pagar el remedio. Bastante gente buena siente desesperanza. Pero, como dijo Ortega, las esperanzas hay que guardarlas bien abrigadas porque no son muchas.

En moral por descontado que ha habido y hay innovaciones. Mantengo que no es cierto que la fisura de la que Rousseau se quejaba se haya ya convertido en un abismo entre nuestro progreso técnico y nuestra mejora moral: la innovación moral mayor ya la tenemos producida mucho antes de que nuestra capacidad técnica se desatara. Hablo del universalismo.

\section{El Universalismo}

El universalismo es la base del humanismo. Imaginar una humanidad única y un mundo solo es la condición previa y trascendental del humanismo. La humanidad única fue imaginada muy pronto, por el filósofo griego Antifonte ${ }^{20}$, pero probarla esa verdad práctica llevó toda la enorme expansión exploratoria que llamamos Modernidad. Primero el mundo se enormizó, comprendiendo en ese camino de desmesura el mejor conocimiento del cosmos que la nueva teoría del cielo nos diera ${ }^{21}$. Y a medida que los cielos se hacían infinitos nuestro pequeño lugar en el cosmos comenzó a parecernos menos seguro y más frágil. También nuestra historia cambió, se universalizó.

Comencemos por el mundo: Un filósofo alemán del siglo XX, que nunca siquiera estuvo muy de moda, Arnold Gehlen, nos regaló esta terminología que ahora decido usar. En su opinión, bien fundada, el mundo y en el mundo no había nada de intuitivo; casi nada era tampoco evidente. y, desde luego, no

fianza común en la andadura solidaria de ciencias y moral, que era el subtexto sobreentendido en la noción ilustrada corriente de progreso.

20 Papiro de Oxyrhyncos, Col II (266-299H) en Sofistas, testimonios y fragmentos, Gredos, Madrid, 1996.

21 Todavía Kepler es capaz de imaginar un mundo descentrado pero con una divinidad vigilante que lo protege y un ser humano rey: «Creador supremo del mundo ¿con qué razón te obligó el pequeño, humilde colono de tan exiguo terruño, el hijo de Adán a tener cuidado de sus cosas? Sin merecerlo lo contemplas, lo elevas a lo sublime y, sin ser de la raza de los dioses, ... a todos tú ordenas someterse a su imperio y mano poderosa» El secreto del Universo, Altaya, 1994, p. 219. 
había uno solo ${ }^{22}$. No era Gehlen partidario de la pluralidad de los mundos habitados, como Bruno, por caso, sino que se refería a lo mismo que el verso de Paul Eluard «hay muchos mundos, pero están en éste».

Para el mundo humano, que es una intrincada red de mundos grupales y particulares, además de institucionales y trascendentales, sólo para este tejido, existe la conciencia de sí y la pregunta por el sentido. Y por lo mismo existe la ética. Sin embargo, aun el mundo humano ha sido hasta hace muy poco bastante más estrecho de lo que lo conocemos. Cada comunidad humana, cada grupo ha puesto sus fronteras a la humanidad allí donde ese grupo y su normativa terminaba.

La humanidad limita con la tribu, como lo llegaría a expresar LéviStrauss. El mundo ha sido, pero nunca ha sido global. La construcción de la universalidad ha constituido hasta ahora, y lo sigue siendo, nuestra tarea más difícil y titánica. Utilizamos la universalidad para razonar, pero no somos de nuestra propia naturaleza moral, universalistas. Y si lo somos lo disimulamos muy bien desde los albores de la especie. Se llevan ahora novelas que transcurren en la prehistoria; y resulta chusco observar con qué tranquilidad sus autores exportan a tan lejano tiempo nuestros sentimientos y relaciones actuales. Empero, las vivencias morales primitivas están asociadas con la defensa del grupo propio y el todo vale con los extraños.

La regla de oro «no hagas a otro, - sea quien sea ese otro- lo que no quieras que te hagan a ti» es bastante moderna: nos la encontramos cuando ya el Mediterráneo es prácticamente una ecumene ${ }^{23}$, un mundo conocido y regular. Es el primer despunte de ese novísimo tipo de moral al que llamamos ética: queremos tener preceptos que sirvan para situaciones previstas y no previstas, por lo tanto tienen que tener un alto nivel de generalidad ${ }^{24}$. Del mismo modo que previsto, no previsto y general se está volviendo el mundo. Queremos principios, normas de normas, que sean fáciles de enunciar y fáciles de defender, que tengan pocas o ninguna excepción, que quepa usar con

22 El Hombre: su naturaleza y su lugar en el Mundo, A. Gehlen (1974). Editado en España por Sígueme en 1980. Es también Gehlen en parte el origen de la más conocida teoría los tres mundos de K. Popper. Existe un mundo externo a nosotros, material, que sigue su propia legalidad; tenemos también el mundo de nuestras representaciones subjetivas: Y finalizamos lo que entendemos por Mundo cuando añadimos la externidad de nuestras innovaciones ideáticas e institucionales. En el fondo ambos beben de otro filósofo, N. Hartmann, que fue el primero en presentar esa sistemática.

23 Aunque se le suele atribuir su formulación a Confucio, lo cierto es que su aparición constatable ocurre en el helenismo, por ejemplo, a fortiori, en Demócrito que afirma ser preferible padecer un mal que cometerlo. Aunque probablemente tiene razón Amitai Etzioni cuando afirma que «este precepto aparece en varias culturas en versiones diferentes» (La nueva regla de oro, Paidós, 1999, p. 18), el problema es más bien su alcance, la frontera del grupo dentro del que se aplica. Por lo que toca a Confucio, algunas de sus analectas reflejan simetría, pero con contenidos complicados, por ejemplo la 18 del libro XIII; vid. Analectas, Círculo de Lectores, 1999, p. 168.

24 M. Douglas, Pureza y peligro, Siglo XXI, 1991, pp. 152 y ss. 
seguridad. Eso es una ética. Y los queremos porque los necesitamos. Pero la firme base de cualquiera de las éticas que han sido imaginadas es el universalismo; o, si se prefiere, la universalizabilidad, por recordar el modo lingüístico en que Hare lo teorizó ${ }^{25}$. Es la ruptura del enquistamiento previo del individuo en sólo su grupo de sentido. Esa apertura es el fundamento, llámesele después razón o por otros nombres, de la posibilidad misma de una ética. El universalismo que del mundo antiguo pasó a la base de las formas religiosas inclusivas, singularmente de los dos monoteísmos inclusivos, cristianismo e islam.

Ese mismo universalismo que no fue capaz de aflorar en la cultura renacentista como una ética porque lo vedaba el paradigma estético señorial; la ética entonces refluyó de nuevo hacia las formas religiosas y alimentó la Reforma. Sólo en el siglo ilustrado fue posible la doble presentación, como razón y como sentimiento: principio imperativo racional en Kant y sentido moral en Hume. «Respeta la humanidad en ti y en los otros»; la simpatía entre los seres humanos es el principio de la vida social y de la felicidad individual; es un sentimiento, pero universalmente tenido ${ }^{26}$.

El humanismo estaba adquiriendo en el siglo de las Luces sus moldes, los a priori del sentimiento y el razonamiento universales, la felicidad del mayor número, la utilidad, pero también iba recolectando sus primeros contenidos positivos. Cuando vemos nacer en las primeras declaraciones y constituciones la serie de derechos, libertades y dignidades individuales, sabemos que es el espíritu humanista quien les está dando aliento. Aliento y contenido. Siempre las reflexiones éticas cuentan con razón, sentimiento y consejos para el manejo del sí propio. Por lo que toca a la contienda entre las ciencias y las humanidades, algunas innovaciones hemos producido.

\section{El último debate del Humanismo}

Puesto que he tomado el socorrido recurso de guiarme por el nombre, he de recalar en la tercera gran ocurrencia del término humanismo, que se produce en el pasado siglo y vinculada a un debate todavía, pienso, no del todo digerido. En los últimos cincuenta años el humanismo se ha popularizado, pero no ha tenido buen nombre intelectual. Las referencias inmediatas son de Heideg-

25 «Universalizabilidad»y «superveniencia» fueron consideradas por Hare características de cualquier lenguaje moral; The Language of Morals, O.U.P (1952); vid. especialmente pp. 142 y ss. edición de 1972 .

${ }^{26}$ Hume, que lo describe, sin embargo lo particulariza: «en general puede afirmarse que en la mente de los hombres no existe una pasión tal como el amor a la humanidad, considerada simplemente en cuanto tal y con independencia de las cualidades de las personas, los favores que nos hagan o de la relación que tengan con nosotros»; esto es, no existe un sentimiento universal de simpatía por la humanidad dicha también en universal; tenemos simpatías concretas y son ellas las que nos hacen obrar moralmente; pero todos las tenemos. Tratado de la Naturaleza Humana, ed. esp. a cargo de Félix Duque, Editora Nacional, Madrid, 1977, pp. 704-705. 
ger, pero los ecos que se funden en él vienen de los proféticos finales del siglo XIX. Probablemente se pueda espigar en el filósofo de la maza una formulación brillante y seca de lo que afirmo. Nietzsche se expresa sin ambages, como en todo: «El hombre es algo que tiene que ser superado» ${ }^{27}$. Pero tras la era del hombre no se abrió la del superhombre, como esperaba, sino que se cumplió otro de los peores temores del profetismo nietzscheano, la Gran Guerra ${ }^{28}$. Malos tiempos para el humanismo que fue incapaz de pararla antes de que se iniciara, y para el socialismo humanista, al que le ocurrió otro tanto.

La razón, por el contrario, vino a reposar en las manos de los que habían avisado de la inanidad de las ideas para hormar las prácticas, de Gustave LeBon y de Pareto ${ }^{29}$ : no hay racionalidad colectiva, luego no hay posibilidades para la buena acción colectiva; el ideal humanista ha muerto por sus altas dosis de ingenuidad. Pareto es concluyente: en política las consideraciones éticas son una derivación de «religiones intelectuales» y lo contante es que la única verdad es la fuerza ${ }^{30}$.

\section{El antihumanismo}

El período de entreguerras fue particularmente duro con el humanismo. Tomas Mann, en Doctor Faustus ${ }^{31}$, desarrolla ante quien lee las gradaciones sutiles de la historia del antihumanismo en la primera parte del siglo XX. El narrador lo encuentra por vez primera de la mano de Breisacher, personaje colocado al filo de la Primera Guerra, que no es sino un portavoz de Spengler. Pero se incrementa en el período de entreguerras donde se funda con la sospecha sobre la libertad y la burla acerca de la democracia ${ }^{32}$. «Nadie extrañará

27 Zaratustra, Alianza, Madrid, 1972, p. 275. Una glosa, con mejor escenificación del contexto de ideas en el propio Nietzsche, la que comienza por «Nosotros hemos trastocado todo lo aprendido. Nos hemos vuelto más modestos en todo. Al hombre ya no lo derivamos del espíritu..», El Anticristo, Alianza 1974, p. 38.

28 Son sus cartas de 1889 , ya en la última de sus crisis, proféticas a los mandatarios europeos, cartas de loco, cuyos destinatarios nunca conocieron en que avisaba de la existencia de una juventud europea que sería lanzada a la muerte.

29 Sirva esta cita del primero, bastante anterior a los acontecimientos: «Los filósofos del siglo pasado se consagraron con fervor a destruir las ilusiones religiosas, políticas y sociales de las que habían vivido nuestros padres durante prolongados siglos. Al destruirlas han cegado las fuentes de la esperanza y la resignación. Tras las quimeras inmoladas han hallado a las fuerzas ciegas de la naturaleza, inexorables para la debilidad y que no conocen la piedad. Pese a todos sus progresos, la filosofía no ha podido ofrecer aún a los pueblos ningún ideal capaz de ilusionarlos... Las masas no tienen jamás sed de verdades», Psicología de las masas, Morata, 1983, p. 84. Pareto, por su parte, llega a escribir la expresión «jerga humanista» en varios lugares, por ejemplo en Forma y equilibrio sociales extracto del Tratado de Sociología General, editado por Alianza, Madrid, 1980, p. 151.

30 Pareto, op. cit., p. 135 y ss.

31 Ed. esp. Plaza y Janés, p. 753.

32 Op. cit., pp. 852-53. 
que durante las conversaciones de aquella vanguardia de la cultura crítica, representaba un papel importante una obra publicada siete años antes de la guerra, las Reflexiones sobre la violencia de Sorel... su aserción de que una sola idea, hacer la guerra, podía unir a los pueblos de esta parte del globo, todo aquello permitía llamarlo el libro de aquellos tiempos». Mann presenta a la élite intelectual centroeuropea divirtiéndose «con una situación preñada de elementos espantosos» $\mathrm{y}$ «considerándola como un hecho consumado e inevitable» ${ }^{33}$. Son los tiempos de la Revolución rusa y la República de Weimar. Son las alabanzas intelectuales a un «neobarbarie consciente». En resumen: se trataba de abjurar de toda compasión, obra de la época burguesa, de modelar la humanidad de conformidad con épocas duras y siniestras, desdeñosas del sentimiento humano, para preparar una era de grandes guerras y revoluciones que nos devolvería sin duda a épocas muy anteriores a la civilización cristiana de la Edad Media» ${ }^{34}$. Todo ello pensado con adhesión, sin crítica alguna de orden moral. Lo que Mann define como «la vecindad entre el esteticismo y la barbarie» ${ }^{35}$. Es el de Mann en Doctor Faustus el mismo paisaje que un estudioso, Peter Gay, nos ofrece en La cultura de Weimar ${ }^{36}$. En esta obra se analiza aguda y profundamente el juvenilismo comunitarista presente en el espíritu de los tiempos y se hace a la obra de Heidegger partícipe de la eclosión de tópica y terminología que le dieron forma.

Todo esto nos pone a las puertas del debate del humanismo en el siglo XX. El siglo más convulso que Europa ha conocido tuvo una terrible primera mitad. La Gran Guerra, la posterior guerra civil española, la Segunda Guerra Mundial no fueron acontecimientos en los que poder precisamente fundamentar la resurrección del credo humanista. Por verme en la obligación de dar la razón a Snow, fueron algunos científicos quienes más se ocuparon de ello, sobremanera Einstein ${ }^{37}$. A la postre, el socialismo también lo abandonó, como previamente lo había hecho el comunismo. Prácticamente cercado dentro de su propia ortodoxia sobrevivió, tenue, el humanismo cristiano. Pero fue en la segunda parte de esa época, poco antes del albor de la otra mitad del siglo, cuando un primer repunte se produjo. A la filosofía arribó ese eco durante el debate que dos figuras principales sostuvieron acabada la horrible contienda: Heidegger y Sartre.

33 Ibidem, pp. 54-55.

34 Ibidem, p. 859

35 Ibidem, p. 862.

36 (1968), Argos Vergara, 1984, pp. 90, 94 y ss.

37 Aunque tuviera defensores tan bien aceptados como Einstein, por ejemplo. En realidad bastantes figuras intelectuales realizaron continuas iniciativas para apuntalar una nueva sociedad política internacional y un credo humanístico. Destaco a Einstein porque sus breves escritos son, sin embargo, contundentes, como fueron en su día eficaces. Están compilados en Sobre el humanismo, escritos sobre política, sociedad y ciencia (1950), Paidós, Barcelona, 1995. Previamente, 1932, es también destacable su correspondencia con Freud a propósito de la guerra, ¿Por qué la guerra?, editado en Minúscula, Barcelona, 2001. 


\section{El tercero: Sartre y Heidegger}

No puedo pretender exponer ni aun resumir ese tracto del diferendo, así que me limitaré a un boceto somero. En 1948 Sartre decide oponerse a las objeciones que diversos críticos hacen a su pensamiento, que está en trance de consolidación. Pero se le reprocha que es insolidario, pesimista, irracionalista descreído de los valores eternos... y esto desde el catolicismo, el marxismo y el tono intelectual corriente. Realiza Sartre una conferencia que dará origen a un opúsculo, El existencialismo es un humanismo; el autor nos da una pista cuando comienza: «Muchos podrán extrañarse de que se hable aquí de humanismo... en todo caso, entendemos por existencialismo una doctrina que hace posible la vida humana y que por otra parte declara que toda verdad y toda acción implica un medio y una subjetividad humana» ${ }^{38}$. Solemos decir «qué humano» ante las partes más sórdidas de lo que somos capaces de hacer, eso es el verdadero pesimismo. El humanismo tiene otra raíz, doble: en lo sucedido, que por la no existencia de Dios los valores pagarán un precio, en lo ontológico, pensar que la existencia precede a la esencia. El humanismo es una derivación del giro antropocéntrico que solamente el existencialismo completa. El más coherente, afirma Sartre, es el ateo, porque «declara que si Dios no existe, hay por lo menos un ser en el que la existencia precede a la esencia, un ser que existe antes de poder ser definido por ningún concepto, y que este ser es el hombre, o, como dice Heidegger, la realidad humana». El hombre es un proyecto que se vive subjetivamente y esto quiere decir que «el hombre es responsable de lo que es» ${ }^{39}$. El hombre se elige y porque lo hace, para sí y para los demás, sucede que nuestra responsabilidad es la mayor que podamos pensar. Cada uno de nuestros actos es ejemplar. No hay naturaleza humana, ni hay determinismo, sino que somos libres, en verdad estamos condenados a ser libres. Y no hay signos en el mundo: Ni tampoco ninguna moral general puede indicar lo que hay que hacer. Esa es la condición humana ${ }^{40}$, tomando prestada la expresión de Malraux. Aunque las situaciones históricas puedan variar, lo que no varían son los grandes límites: estar en el mundo, en el trabajo, con los otros y ser mortal. Y todo proyecto tienta el límite. La moral se parece a la obra de arte, en el arte y la moral hay creación e invención. «El hombre se hace al elegir su moral y la presión de las circunstancias es tal que no puede dejar de elegir una» ${ }^{41}$. El humanismo sartreano comienza a presentarse como una indagación en la libertad, que es una búsqueda individual de algo que es tenido en común. Los seres humanos son decididamente contingentes, podrían no haber existido; por lo mismo eligen lo que son: «Si he su-

\footnotetext{
38 En Existencialismo y Humanismo, Sur, Buenos Aires, 1949, p. 12.

39 Ibidem, p. 17.

40 Malraux había titulado así en 1933 su clásico y durante el debate, no hay por qué olvidarlo, ocupaba el Ministerio del Interior.

41 Op. cit., p. 37.
} 
primido a Dios Padre es necesario que alguien invente los valores» ${ }^{42}$. Esto es el humanismo. Porque, por último, Sartre aclara que hay dos humanismos: Uno es una teoría que toma al hombre como fin y como valor superior, diríamos que de teocéntrico se ha vuelto antropocéntrico; éste, afirma Sartre, «es absurdo». Que seamos lo más alto, sólo podría afirmarlo los caballos o los perros. No hay humanidad a la que rendir culto, como pretendía Comte. Otro es el humanismo existencialista; consiste en entender ese perpetuo rebasarse en que se da el existir como hombre: «lo llamamos humanismo porque recordamos al hombre que no hay otro legislador que él mismo» y que no es volviendo hacia sí, sino buscando fuera de sí un fin que es tal o cual realización o liberación cuando se realizará en cuanto humano. Y, aunque Dios existiera, esto no cambiaría ya. Aquí han llegado ahora las cosas.

El pequeño y fuerte texto de Sartre produjo reacciones en muy diversos frentes. Me interesa destacar que quienes arguyeron en contra afirmaban que había, en su presente, no sólo dos humanismos, sino cuatro o cinco, porque todos quería subirse a esa plataforma: «Todo el mundo es humanista en esta hora... Si los marxistas pretenden ser humanistas, las diferentes religiones, los cristianos, los hindúes y muchos otros, pretenden también ser ante todo humanistas... y de una manera general todas las filosofías» se le replica ${ }^{43}$. Más que el argumento, me interesa retener el dato: el humanismo está siendo vindicado, el problema es que por demasiada gente. Pero su triunfo no será sino efímero.

\section{El vecino del ser}

Heidegger había sido invocado por Sartre como el otro existencialista. Esto le dio oportunidad de intervenir cuando el asunto se produjo como conferencia, en 1945 mediante una carta. «Sobre el humanismo» es una carta dirigida a Jean Beaufret ${ }^{4}$ de la que provienen varias de sus afirmaciones más conocidas, comenzando por la rotunda «la palabra es la casa del ser». Con independencia de las razones por las que Heidegger quisiera entrar en el debate del humanismo, precisamente él, que se ofrecen a muchas interpretaciones incluidas las malévolas ${ }^{45}$, los argumentos que empleó, que es lo que ahora importa, tuvieron todos parecida solemnidad; me veo obligada a elegir algunos:

42 Ibidem, p. 41.

43 Naville, op. cit., pp. 47 a 57.

${ }^{44}$ Quien le había visitado en su cabaña acompañado por varios brillantes alumnos, entre los que se encontraba Lyotard.

45 Steiner, Farías, etc. Steiner destaca la continuidad de Heidegger con Agustín, Lutero, Pascal y Kierkegaard, así como su «pertenencia al campo»... «El campo y el bosque están en el corazón del mundo de Heidegger» de donde infiere una serie de líneas presentes en el pensamiento europeo que combinan deshumanización con técnica, Heidegger, FCE, 1983, p. 194. Por lo que toca a Farias, él es quien reproduce el párrafo de la carta en que Heidegger dice «aquí - en Friburgo - se me ataca. De todas maneras yo me apoyo en París donde soy el filósofo de moda», Heidegger y el nazismo, Muchnik editores, 1989, p. 383. 
El primero que para saber del hombre hay que acudir a fuentes anteriores a la aparición de la razón socrática. Este argumento ya era en verdad de Nietzsche, del Ocaso de los Ídolos, en particular, donde llamaba, creo recordar a Sócrates, «gallina cristiana»; ahora se acompañaba con otros. «La historia del ser sustenta y determina cada condición y cada situación humana» ${ }^{46}$. Pero ¿qué es? El ser precede al pensar. Se ha dejado ya de vista en el inicio, en Platón y Aristóteles. ¿Para qué cosa es un término? ¿Por qué retener al día de hoy el término humanismo? Los ismos son sólo «mercado de la opinión pública». Los griegos no los necesitaban. «Ni siquiera llamaron filosofía al pensar» ${ }^{47}$. El ser tiene poder sobre el pensar y «así sobre la esencia del hombre, esto es: sobre su referencia al ser» ${ }^{48}$. Ahora estamos en el ser y debemos esperar que «nos dirija la palabra». Por si no llegare a hacerlo, Heidegger avanza que humanismo es «meditar y preocuparse de que el hombre sea humano y no inhumano, esto es, contrario a su esencia». De nuevo estamos ante otra circularidad que debe remitirnos a la esencia. La humanitas, afirma, es invento romano resucitado en el Renacimiento, siempre contra un bárbaro y siempre es «revivir de lo griego». Pero, y aquí aparece el punto, «si se entiende por humanismo en general el empeño destinado a que el hombre esté en libertad de asumir su humanidad y en ello encuentre su dignidad, entonces, según se entienda la libertad y la naturaleza del hombre, es el humanismo en cada caso algo distinto» ${ }^{49}$. Ése es el caso de Sartre, de manera que, sin aún aclarar que entienda el propio Heidegger por humanismo, ya ha mostrado su disenso con Sartre.

«Todo humanismo, - continúa-, o se funda en una metafísica o se convierte a sí mismo en el fundamento de una metafísica». Y añade: «Toda determinación de la esencia del hombre que supone la interpretación del ente sin la pregunta por el ser, sea sabiéndolo o no, es una metafísica» ${ }^{50}$. Toda metafísica es humanista y todo humanismo «es y será metafísico» ${ }^{51}$. No es que el humanismo olvide la pregunta por el ser, es que la impide. El humanismo da por hecha la esencia porque «siempre y cada vez se funda la esencia del intelecto en que para cada captación del ente en su ser, el ser ya está descubierto (=aclarado) y se realiza en su verdad» ${ }^{52}$. Apresurando: sea pensado el hom-

46 Op. cit., p. 66.

47 Ibid., p. 69

48 Parece simplemente un círculo argumentativo, pero es en realidad la glosa de un viejo tema hegeliano, como tantas veces ocurre en Heidegger: de si el pensamiento ocurre una vez que la realidad ha transcurrido. Heidegger intentó volver sincrónico el hegelianismo, extraño empeño que explica bastantes de sus insuficiencias de fondo. Pero, en fin, en tal asunto, más general y epocal, le acompañaba toda la Teoría del Valor.

49 Op. cit., p. 73.

50 Op. cit., p. 74. De nuevo es obvio el intento de salvar la relación con Sartre, en la suposición de que Sartre «sí sabe».

51 Ibidem.

52 Ibid., p. 75. 
bre desde la metafísica como animalidad con diferencia, sea alma, mente, sujeto, persona, espíritu. Esto es lo que la metafísica hace: poner uno por otro. Hay que ir más atrás y poner la procedencia, porque en la procedencia está el porvenir de la humanidad histórica ${ }^{53}$. Rápidamente Heidegger corrige el tiro: «La metafísica piensa al hombre desde la animalitas y no lo piensa hacia su humanitas» ${ }^{54}$. El hombre, por el contrario está en la «ec-sistencia», en «el despejo del ser». Por ello el hombre «está destinado a pensar la esencia de su ser». Y por el medio, el medio mismo, es el habla. Con citas recurrente a Ser y Tiempo, precisamente por su basal antihumanismo, Heidegger vuelve a su posición de partida: Sartre sólo ha cambiado los términos de la metafísica platónica al afirmar que la existencia precede a la esencia; y eso es así porque «continúa en el olvido de la verdad del ser» ${ }^{55}$.

Está ausente la pregunta por el destino del ser. «Para que nosotros, la gente de hoy, alcancemos a ingresar en la dimensión de la verdad del ser para poder pensar en ella, tenemos previamente que aclarar como le importa el ser al hombre y cómo le embarga (=interpela)», de donde se sigue que «las más altas determinaciones humanísticas de la esencia del hombre, no alcanzan a lo que es propiamente la dignidad del hombre» ${ }^{56}$. A partir de este momento Heidegger se enreda en una autodefensa por el antihumanismo de Ser y Tiempo. Pero debe concluir y lo hace: «El hombre es el guardián del ser y la ec-sistencia es cuidado. El ser es «más amplio y lejano que cualquier ente» $\mathrm{y}$, sin embargo, «lo más cercano». Retornemos a los presocráticos, cuando el ser hablaba. Ahora somos apátridas por el abandono del ser en que se halla el ente. Y «la apatreidad se convierte en destino mundial».

Retengamos lo que ocurre ahora, en este proceso del ente que es mundo y sólo una fase de la historia del ser: «El peligro al que es empujada cada vez más claramente la Europa que hasta ahora ha existido, consiste presumiblemente en que ante todo su pensar - otrora su grandeza - se quede atrás en el proceso esencial del destino mundanal que alborea y que, sin embargo, en los trazos fundamentales de su origen esencial, sigue siendo determinado por lo europeo» ${ }^{57}$.

En conclusión, debe irse contra todo humanismo anterior, siempre metafísico, pero no abogar por lo in-humano, sino por otra lógica que no se sustenta en la negación, sino en la superación. Por utilizar un modo, mi comparación diría que las tablas del barco-historia hablan de sus singladuras sin necesidad

53 Se me excusará que abandone momentáneamente la exposición para sorprenderme ante este terrible salto y se me permita considerar que si la procedencia es el futuro, con Darwin tenemos bastante. Y considerar, al par, que Heidegger afirma que nuestro parentesco con el animal es «abismal» y «difícilmente pensable» (Ibid., p. 79).

54 Ibid., p. 76.

55 Ibid., p. 81.

56 Ibid., p. 83.

57 Op. cit., p. 95. 
de relatarlas. «Humanitas al servicio de la verdad del ser, pero sin el humanismo en el sentido metafísico» ${ }^{58}$. El pensar subsiste, pero está «en el descenso a la pobreza de su esencia provisoria» ${ }^{59}$. En resumen, este es el haz, la centralidad del ser no puede resultar evadida y por ello el humanismo, todo el habido, es un paso en falso. Heidegger cierra su opúsculo con un referencia al habla, «el pensar abre surcos insignificantes en el habla», topós que, para mi fortuna, permite realizar con simplicidad el tránsito al tercer escalón de este camino.

\section{De Lévi-Strauss a Foucault: El fin de la Era del Hombre}

Y éste su envés: La cuestión volvió a Francia al filo del 68. En realidad la adelantó Lévi-Strauss en su polémica acerca del humanismo, también con Sartre. Sartre en la Crítica de la Razón Dialéctica se había preguntado de nuevo por la capacidad del sujeto de expresar el universal. Era una cuestión acuciante dado el nominalismo de fondo y fundamento en el pensamiento existencialista ${ }^{60}$. En 1962 el estructuralismo de Lévi-Strauss se desmarca del humanismo por razones aparentemente de paradigma epistemológico. En el capítulo final de El Pensamiento Salvaje Lévi-Strauss, que ha utilizado en ocasiones terminología sartreana, denuncia la inconsistencia de lo que Sartre intenta edificar como razón dialéctica ${ }^{61}$ por oposición a la razón analítica. Aceptando parte de las clasificaciones sartreanas en modo irónico, Lévi-Strauss se define como esteta: «condición requerida para que se atreva a emprender la resolución de lo humano en no humano. Estetas pues Sartre aplica este término a quienes pretenden estudiar a los hombres como si fuesen hormigas» ${ }^{62}$. Tras asegurar que las hormigas no son tan fáciles como algunos pretenden creer, Lévi-Strauss ataca las dicotomías corrientes: «La explicación científica no consiste en el paso de la complejidad a la simplicidad, sino en la sustitución de una complejidad menos inteligible por otra más inteligible. En nuestra perspectiva, por consiguiente, el yo no se opone al otro, como el hombre no se opone al mundo: las verdades captadas a través del hombre son «del mundo»y son importantes por eso mismo» ${ }^{63}$.

58 Ibid., p. 108.

59 Ibid., p. 121.

60 En toda esta interpretación de esa obra de Sartre me guío por el espléndido trabajo de Celia Amorós, Diáspora y Apocalipsis, estudios sobre el nominalismo de Jean Paul Sartre, Alfons el Magnanim, Valencia, 2000.

${ }^{61}$ El asunto es, por lo demás, sumamente epocal; no se olvida que «dialéctica» se repartía con profusión, incluida la «lógica dialéctica», pero las razones de fondo eran otras, la humanidad única. Op. cit., FCE, México, 1964, pp. 355 y ss.

62 Op. cit., p. 357.

63 Ibidem, p. 359. Deben señalarse los aspectos casi kuhneanos de esta formulación, que el mismo Lévi-Strauss explica en la nota extensa que la cierra. 
Tras este rechazo del uso existencialista de la terminología hegeliana se presenta el que las ciencias humanas, sobremanera la etnología y la antropología, necesitan pensar sin «el hombre» que no es para ellas más que una rémora. Bien al contrario, deben disolverlo. Cuando pensamos al «hombre» pensamos muy probablemente dentro de nuestro marco y por lo tanto fuera del punto de vista adecuado, que no es general, porque tampoco lo general existe dado que nosotros no lo encarnamos. La filosofía del yo es estrecha para contener la multiplicidad que la humanidad revela.

Comienzan los tiempos postcoloniales y ello se manifiesta en las acusaciones de etnocentrismo que el paradigma sartreano recibe. Porque, en opinión de Lévi-Strauss «deja escapar la prodigiosa riqueza y la diversidad de las costumbres de los usos y de las creencias; se olvida que a sus propios ojos cada una de las decenas o centenas de millares de sociedades que han coexistido sobre la tierra, o que se han sucedido desde que el hombre hizo su aparición, se ha valido de una certidumbre moral - semejante a la que nosotros mismos podemos invocar - para proclamar que en ella, - aunque se redujese a una pequeña banda nómada o a una aldea perdida en el fondo de los bosques-- se condensaban todo el sentido y la dignidad de que es susceptible la vida humana» ${ }^{64}$. La mirada de Sartre es tan cerrada como la de un melanesio. «Descartes, que quería fundar una física, separaba al Hombre de la sociedad. Sartre, que pretende fundar una antropología, separa a su sociedad de las demás sociedades» ${ }^{65}$. La historia no es nuestra maestra, sino que meramente despliega ahora en el tiempo lo que la etnología despliega en el espacio. El individuo cree percibir una sucesión ordenada, pero la está fabricando, del mismo modo que el orden que se da a sí mismo, en su autorrelato, es un producto de su ser social, su ser para otros. La multiculturalidad, por lo tanto, no es ningún desorden; es lo que hay. Historia y humanidad no son lo mismo; unirlas en una mixtificación «que se nos pretende imponer con el fin inconfesado de hacer de la historicidad el último refugio de un humanismo trascendental» y todo para reencontrar en el nosotros la ilusión de libertad que cada yo ha perdido ${ }^{66}$. Ni el salvaje lo es, ni existe pensamiento prelógico, ni un grupo humano es más humano que otro. El espíritu científico restablece en sus derechos al pensamiento salvaje ${ }^{67}$.

Cuando Lévi-Strauss repite los postulados fundamentales del relativismo cultural ante los auditorios más calificados ${ }^{68}$, sus argumentos debe decirse

64 Ibidem, p. 360.

65 Ibidem, p. 362.

${ }^{66}$ Ibidem, p. 380.

67 Ibidem, p. 390, sin embargo, al negar los principales supuestos de la fundación de la antropología moderna que Levi-Bruhl estableciera en La mentalidad primitiva (1927) no saca sin embargo la conclusión de la humanidad-una, sino de humanidades inconmensurables.

68 Por ejemplo en Unesco 1951. Raza y Cultura, 1952, un encargo de la institución, sigue hasta hoy siendo citada en ese contexto. 
que son muy bien recibidos. El cierre de la historia colonial se estará produciendo al par que un cambio de paradigma que va más allá de donde Lévi-Strauss lo coloca en estos fenomenales inicios.

Relativismo cultural y fin del humanismo conforman un nuevo modo de saber que tiene por objeto «dispositivos». Ha nacido el estructuralismo. Y la frase que se ha citado de Heidegger aparece profética: Europa por sí misma busca descentrarse. Con independencia de cuál haya sido el fruto final o incluso la coherencia entre ellos de los que entonces se llamaron a sí mismos estructuralistas, han dejado sus huellas también en el debate del humanismo hasta el punto de hacer complicado su mero planteamiento. Para todos ellos universalidad, sentido, hombre... son precipitados, no condiciones.

Entiendo que ejemplificar con un párrafo de una conversación es menos firme que traer a colación un texto, pero Foucault nunca desdeñó que sus conversaciones se publicaran. La cita, no por conocida, deja de ser impactante:

«Entiendo por humanismo el conjunto de discursos mediante los cuales se le dice al hombre occidental: «si bien tu no ejerces el poder, puedes sin embargo ser soberano. Aún más: cuanto más renuncies a ejercer el poder y cuanto más sometido estés a lo que se te impone, más serás soberano». El humanismo es lo que ha inventado paso a paso estas soberanías sometidas que son: el alma (soberana sobre el cuerpo, sometida a Dios), la conciencia (soberana en el orden del juicio, sometida al orden de la verdad), el individuo (soberano titular en sus derechos, sometido a las leyes de la naturaleza o a las leyes de la sociedad), la libertad fundamental (interiormente soberana, exteriormente consentidora y «adaptada a su destino»). En suma, el humanismo es todo aquello a través de lo cual se ha obstruido el deseo de poder en Occidente - prohibido querer el poder, excluida la posibilidad de tomarlo- . En el corazón del humanismo está la teoría del sujeto (en el doble sentido del término). Por eso el Occidente rechaza con tanto encarnizamiento todo lo que puede hacer saltar este cerrojo. Y este cerrojo puede ser atacado de dos maneras. Ya sea por des-sometimiento de la voluntad de poder (es decir por la lucha política en tanto que lucha de clase), ya sea por un trabajo de destrucción del sujeto como pseudosoberano (es decir mediante el ataque cultural: supresión de tabúes, de limitaciones y de separaciones sexuales, práctica de la existencia comunitaria, desinhibición respecto a la droga; ruptura de todas las prohibiciones y de todas las cadenas mediante las que se reconstruye y se reconduce la individualidad normativa. Pienso sobre esto en todas las experiencias que nuestra civilización ha rechazado o no ha admitido más que como elemento literario» ${ }^{69}$.

Aunque descontemos los obvios rasgos sesentaiochistas de lo que Foucault expresa (sobre todo el velo de acracia que cubre el conjunto), desconte-

69 «Más allá del bien y del mal» en Microfísica del Poder, La Piqueta, Madrid, 1979, pp. $34-35$. 
mos los guiños al movimiento juvenilista y sus inspiraciones maoístas (sin contar con la posterior adhesión del autor a la revolución iraní), y aun si restamos también las resonancias evidentemente nietzscheanas de trasfondo, con la voluntad de poder alzándose contra cualquier orden, nos resta una identificación donde se escuchan todos los ecos de lo hasta aquí recorrido, de la $\mathrm{Hu}-$ manitas de Heidegger al relativismo de Lévi-Strauss. Lo que en este párrafo encontramos condensado aparece como sistema en el entramado completo del estructuralismo. Lo que se pensaron primeras realidades son interpretadas como precipitados, ya se trate de la individualidad, el sujeto, la libertad... Un fuerte freudismo recorre todo este tracto del pensamiento y en él la pulsión es lo originario. El humanismo es, ciertamente, norma. Es un después. No tiene, por lo tanto, cabida.

\section{Ciudadanía global. \\ Sobre globalización y multiculturalidad}

El Planeta, tan pequeño y abarcable que puede dársele una vuelta significativa en cuatro días, está recubierto por un velo de mensajes que, si se visualizaran como finos hilos, lo convertiría en un activo capullo de seda. Eso, que viene ocurriendo desde el uso de la señal de radio, se ha incrementado hasta el actual desarrollo de las telecomunicaciones; no tanto ha cambiado el medio, sino que la innovación ha consistido en nuestra nueva y enorme capacidad de almacenar y trasladar datos. Ello, surgido y propiciado por el crecimiento del estado moderno, ahora es la película de comunicación que envuelve el mundo y lo constriñe a utilizar lenguajes comunes. El mundo es una noosfera. De el planeta huye el misterio ${ }^{70}$, escapa a su exterior $\mathrm{y}$, al presente, ni siquiera el silencioso universo agita nuestra imaginación. Comenzamos a entender que, de manera fehaciente, estamos solos. Que el planeta es limitado; que no nos iremos a ninguna parte.

¿Cambiarán estos conocimientos, actuando basalmente, nuestros modos de vida? La noosfera informa de todo ello, pero es un enorme revoltijo donde lo significativo y lo trivial no tienen signos que los separen. Mi insistencia en llamar noosfera al planeta hipercomunicado es un tributo a un filósofo y teólogo injustamente preterido, Teilhard de Chardin. Su concepto de «noosfera» ${ }^{71}$ es en la actualidad recuperado por la Red, los internautas, que le reconocen como predecesor, los teóricos del movimiento Gaia y hasta Tom Wol-

70 Aunque todavía algún reportaje de la N. G. se anuncie con el inverosímil reclamo de «conocerán culturas no tocadas por la mano del hombre».

${ }^{71}$ Es la «capa pensante»; «fuera y por encima de la biosfera hay una noosfera», El fenómeno humano, Taurus, Madrid, 1971, pp. 219 y ss. Teilhard recogió este concepto de Vernardsky, pero lo transformó; quizá lo más fascinante de su pensamiento sea su teoría de la compresión humana y su destino en el punto omega, pero no pueden tratarse ahora. 
$\mathrm{fe}^{72}$. De Teilhard es la formulación «piel pensante». En sus póstumos, $E l$ medio divino ${ }^{73} \mathrm{o}$ El fenómeno humano, se explicita y está presente dentro de la estructura organicista de todo su pensamiento ${ }^{74}$. Muy probablemente fue Teilhard la inspiración principal de McLuhan, que es sin duda quien avanzó la forma general de mundo hipercomunicado ${ }^{75}$.

El asunto es simple: Si la comunicación tiene estructura donde producirse y ampliarse, se supera la sensación de desorden y además aparece la interlingua planetaria ¿esta nueva forma es capaz de cambiar los contenidos? ¿Concita esta universalidad al universalismo? ¿Toma de nuevo el humanismo arranque?

\section{Universalismo y Democracia}

Sería un error, y grave, pasar por encima del estado multicultural e incluso pluricivilizatorio de las diversas humanidades que conviven en el planeta. Añado la palabra «civilización» como recordatorio de Huntington, cuyo antihumanismo ya no se sustenta, como el de los antropólogos del siglo pasado, en los pequeños grupos humanos, sino en los datos de la geopolítica. Pero como a Huntington habrá que volver, me detengo antes, en un punto anteriormente sólo insinuado, en la causa profunda de la apertura del debate del humanismo al término de la Segunda Guerra.

¿Qué y quién pedía tanto humanismo en ese final de guerra como para que apareciera la polémica? Arriesgo que dos fuentes: la utilización bélica de la energía nuclear y la Declaración del 48. El mundo se estaba volviendo global de un modo infame. La globalización se traducía en la amplitud del escenario de la Guerra, - todos los continentes menos uno-, y la inusitada capacidad de destrucción que había comparecido en ella, lo que sus contemporáneos llamaron «la bomba» ${ }^{76}$. Era preciso volver sobre lo andado, reparar lo irreparable. Resucitar la voluntad buena. Construir una paz duradera. Renovar la sociedad de Naciones y sustituirla por la ONU. El mundo tenía graves y grandes urgencias.

72 De este último entresaco la frase: «Ha tenido que estallar la actual webmanía para que casi medio siglo después, sus románticas teorías adquirieran vigencia»; Wolfe, «Infoverborrea, polvos mágicos y el hormiguero humano», en El periodismo canalla y otros artículos (2000), Ediciones B, Barcelona, 2001.

73 Taurus, Madrid, 1959.

${ }^{74}$ Un organicismo plotiniano que se despliega e implica una focalización finalista no ensayada por la filosofía cristiana desde Nicolás de Cusa.

75 La hipercomunicación nos sume en lo que McLuhan llamaba «espacio acústico» y que ahora solemos llamar ciberespacio; según M.McLuhan la noosfera, por sí misma, cambiaba las condiciones anteriores de la existencia humana, por lo que, en una primera fase, lo exterior debería ser percibido como caos. La aldea global, Gedisa, 1996, p. 135.

76 Einstein es particularmente insistente en este punto, lo que bien se comprende, en especial en sus artículos «Guerra atómica o paz» o «La amenaza de una destrucción masiva», ambos en el ya citado Sobre el humanismo, pp. 69 y 85 . 
Y aunque las respuestas a tales urgencias no parecen estar a la altura de sus incitaciones, - me refiero en particular a las respuestas filosóficas-, algunas cosas, quizá sin tenerlas muy en cuenta, aquel mundo hizo. Bien es cierto que no muchas, porque la dinámica de bloques lo mantuvo cerrado y parcelado durante cuatro décadas. Mas los pensadores humanistas, con todo, no estuvieron quietos. No cabe olvidarse de Jaspers o de Fromm; este último dedicó al humanismo casi los últimos veinte años de su actividad. En el sesenta y ocho encontraremos todos sus ecos: «¿qué ha sido del hombre? Totalmente ocupado en producir, vender y consumir cosas, el hombre mismo se va convirtiendo en cosa... el mayor peligro en nuestro presente sistema quizá esté en que las cosas, los aparatos y el éxito técnico resultan más atractivos que la vida y el desarrollo»» ${ }^{77}$. El humanismo de esa época, que todavía no es ecologista, se descuelga de la epistemología para llegar a la política informal. Se difunde sobre moldes marcusianos ${ }^{78} \mathrm{y}$ excita la revolución juvenilista. Lo conocemos de vividas. No llega a alcanzar demasiado crédito académico.

Pero ¿qué ocurre ahora, cuando el mundo parcelado por la guerra fría se ha ido? El humanismo nos acompaña en ese modo, que llamaré popular, desde hace dos décadas. Se introduce dentro de otros pensamientos soporte, por ejemplo en las religiones new age, está presente sin ser aceptado, por lo menos, directamente. Sin embargo, tiene sus aliados objetivos.

\section{La democracia como pedagogía}

La democracia es el mayor y mejor sistema de pedagogía moral que hayamos sido capaces de inventar. Es muy reciente, joven todavía en la mayor parte de los lugares en que se asienta, y desconocida en gran parte del planeta. Y, como escribe Dahl ${ }^{79}$, sólo cuando la democracia se hace estable, lo que sobre todo sucede después de la Segunda Guerra Mundial, empieza a tener buen nombre. Desde entonces muchos sistemas políticos se dan a sí mismos el nombre de «democracia» cuando ni lo son, ni lo pueden llegar a ser. Recordemos que, por ejemplo el franquismo se autodenominaba «democracia orgánica», o que los comunismos se llamaron también a sí mismos «democracias populares». Que algunas tiranías religiosas se auto proclaman «democracias islámicas». En opinión de Dahl lo que todo esto indica es que la democracia comenzaba hace ya casi cuatro décadas a ser el sistema político de referen-

77 El humanismo como utopía real, Paidós, 1998, pp. 99-100.

78 Que Steiner entiende como derivaciones de Heidegger, op. cit., p. 194.

79 Dahl, La democracia y sus críticos (1989), Paidós, Barcelona, 1992.

80 Cuando F. Fukuyama presentó esto bajo el título El fin de la historia y el último hombre, hubo un general rasgar de vestiduras de todo punto exagerado. Al fin se limitaba a poner datos a favor de que «no hay bárbaros a las puertas» y que «la teoría de la modernización parece mucho más persuasiva en 1990 que hace quince o veinte años», entendiendo por tal la progresiva extensión del capitalismo liberal; op. cit., p. 195. 
cia $^{80}$. Y es cierto que, si bien con graves excepciones, alguna democracia popular y alguna democracia islámica, subsisten y son bastante grandes, las posiciones de las llamadas democracias han avanzado planetariamente ${ }^{81}$. Pero ¿ha avanzado la ciudadanía en cada una de las democracias o existe asomo alguno de ciudadanía mundial? Son dos preguntas que interrogan a la democracia como algo más que un procedimiento.

Pues bien, la plena ciudadanía moderna ${ }^{82}$, entendida como conjunto de seguridades, expectativas y derechos, existe allí donde la democracia es sólida. No hay ciudadanía global, nos consta, como también sabemos que las instituciones internacionales son bastante frágiles. Ni siquiera está claro que haya un decidido interés político de las democracias fuertes por ayudar a la existencia de una ciudadanía global. El mundo sigue pareciendo poco libre, conflictivo y fragmentario. Necesita grandes decisiones apoyadas en virtudes que no abundan: inteligencia, generosidad, confianza, probidad; los estados siguen siendo hobbesianos y recelosos entre sí, como los describió Hegel. La geopolítica impone sus normas y la política internacional acusa los efectos continuos de decisiones maquiavelianas, de estrategias cuyo único fin es «aumentar la potencia», spinozianamente, para consolidar el propio poder. Aunque la utopía lo imaginó, casi nadie en el presente se figura una democracia planetaria, ni un único gobierno para el planeta. Nos consta que las grandes decisiones se escapan al estado nación, pero no hemos autorizado a nadir superior para tomarlas por él o en su lugar; vamos de convenio en convenio, de consenso en consenso, en fin, habermasianamente ${ }^{83}$.

Somos demasiado distintos entre nosotros todavía y sabemos que, con alguna excepción, el panorama no es alentador. Pero, con todo, la democracia es la mayor y mejor maestra de ética que hayamos tenido nunca. Es exigente y universalista. Tiende a fijarnos en la noción de derechos y a la vez en hacer argumentable todo el sistema de deberes. Es, repito, universalista en su horizonte y, en sus contenidos, adelanto, es humanista. La democracia enseña sobre todo a pactar y por ello deflacta per se la violencia, como escribía Aranguren en Ética y Política.

81 El trabajo de S. Huntington La tercera ola (1991) Paidós, 1994, es inobjetable en sus registros cuantitativos, así como sus líneas explicativas, sobre todo lo que llama «efecto demostración», del que destaco que alcanzó objetivos porque aumentó la noosfera compartida; en sus palabras: «La razón fue la tremenda expansión de las comunicaciones mundiales», op. cit., pp. 100 y ss.

${ }^{82}$ Hago la precisión por la extendida costumbre de mantener el término sin matizar y llevarlo al contexto griego; cierto que nuestra ciudadanía guarda con la antigua algunas relaciones, pero no tantas como se suele dar por demostrado. Los mejores trabajos sobre la democracia antigua son, sin duda, los de J. Romilly, Problemes de la democratie grecque, traducido como Los fundamentos de la democracia, Cupsa, Madrid, 1977, y Alcibiades, Seix Barral, 1996.

${ }^{83}$ Sea dicho solamente en el plano metodológico, porque Habermas es muy partidario de una ciudadanía global e incluso del multiculturalismo dentro del estado de bienestar europeo, como lo prueba su ensayo "Ciudadanía e identidad nacional» en Facticidad y validez, Trotta, Madrid, 1998, especialmente p. 643. 
En efecto, la democracia no se limita a ser un procedimiento pacífico para la toma de decisiones, - - lo que la compromete tan sólo con la regla de mayorías- sino que supone también un horizonte de valor que consiste en lo fundamental en la salvaguarda de los bienes básicos: la libertad, la igualdad, la solidaridad. Estos valores básicos sólo dan el marco general que ha sido tarea de las Declaraciones y de las Constituciones, de esos textos con un par de siglos de existencia, hacer más y más preciso. Los valores y prácticas que la democracia encierra fueron expuestos de modo sistemático con ocasión de la Declaración Universal de Derechos Humanos de 1948. Una Declaración Universal que no firmó una notable cantidad de países ${ }^{84}$. Y, aun así, debe decirse que ésa fue la fecha decisiva para dotar al humanismo de contenidos positivos y enumerables. La forma venía dada ya desde el universalismo y la compasión ilustradas, pero la Declaración fue su contenido de mínimos.

\section{El humanismo de hoy}

El humanismo, actual y pasado, no es autoevidente, porque no pertenece a tal orden, sino sólo autorreferente. Es inmanente este humanismo ${ }^{85}$. Tener presente esta distinción puede evitar polémicas pasadas. En el orden de los valores no hay autoevidencia alguna: todos han sido creados y resultan difíciles de mantener. Sin embargo, el humanismo sí es autorreferente, porque toma a la humanidad como un todo y funde con su horizonte su teleología. Es por ello a la vez exigente y compasivo y tiene el defecto que Hegel calculó a esa fusión: puede fijar el marco dentro de una estructura moral pasajera que resulte escasa en sí misma. Difícil es que salte sobre sus propias Rodas a no ser que lo haga a base de abstracciones. Concluyendo, que epistémicamente el humanismo no es una ganga; pero es lo que hay.

$\mathrm{Y}$, en nuestro tiempo, el humanismo tampoco es antropocéntrico. El humanismo como doctrina positiva recoge, cierto es, elementos de tradiciones muy variadas, pero corta con sus referentes de origen para convertirse en una fijación de límites que tiene pretensiones de autosubsistencia. El humanismo actual tiene otra geografía. No por tener remotos orígenes mediterráneos no es capaz de amalgamarse con otras tradiciones completamente diversas. Hay humanismo en Oriente, en Occidente, en el Norte y en el Sur. Cada tradición lo suficientemente fuerte, cada área consolidada, reclama hoy en día haber formado parte de su nacimiento: desde quienes lo colocan en Gandhi ${ }^{86}$ hasta

${ }^{84}$ Hay, naturalmente, varios registros de ello, pero excúseme que, por ahorrar tiempo, remita a mi libro Ética para un mundo global, Temas de Hoy, 2003, pp. 9 y ss.

85 Lamento tener que señalarlo, pero en abril de 2006 la Conferencia Episcopal española alertó sobre «el peligro del humanismo inmanentista» que, mucho me temo, que es el presente y el que hay.

86 Por ejemplo el mismo Gandhi, no sin contradictores, naturalmente, puesto que el hinduismo no es precisamente universalista ni igualitario; el sistema de castas, que está todavía 
las reformulaciones en clave budista de Daisaku Ikeda ${ }^{87}$. Esto no debiera ser disuadido, sino alentado. Comienza a parecerse a lo ocurrido con el término democracia. La victoria siempre tiene muchos padres, y hasta madres.

Florece de nuevo el humanismo y lo hace en muchas partes. ¿Qué lo distingue ahora? Durante el debate del humanismo en el pasado siglo se tiene la impresión de que es sobre todo el antropocentrismo el que se pone en cuestión o al menos es el núcleo de la cuestión tal como se argumenta; yo, sin embargo, sospecho que la denostación de la compasión, que es una de las líneas de fondo, normalmente se encubre. En fin, obviando tal subtexto, debe decirse que el antropocentrismo ya no es posible. Lanzada la tierra fuera del centro del universo por el pensamiento barroco, la humanidad lo fue del centro del planeta vivo, de la biosfera, inicialmente por Darwin ${ }^{88}$, pero las consecuencias de tal enorme movimiento todavía se están haciendo sentir. Las explicaciones religiosas aún no lo procesan en un discurso que lo incorpore. El gran relato evolutivo, omnipresente y de base humanista en su sentido natural, puesto que nos iguala frente al resto, esta vez de verdad y no en los términos religiosos aducidos por Dumont, está sabido, pero no realmente admitido. Tomarlo junto con los restos que quedan del antropocentrismo parece confortar a la mayoría. Y el saber popular, desorientado al respecto, no imagina cómo puede mantener una explicación no naturalista dentro de la admisión del relato que sabe más probable. Bascula entre Desmond Morris y los sociobiólogos populares ${ }^{89}$, pero se resiente de la pérdida del marco religioso anterior.

bastante vivo, no pudo ser el trazo sobre el que Gandhi edificó su magisterio. Más bien sucede que utiliza la misma razón de Dumont sostiene para el caso de Locke; escribe Gandhi: «Estoy convencido de que dios es perfectamente uno. La humanidad, por consiguiente, forma un todo único», Todos los hombres son hermanos, Sígueme, Salamanca, 2002, p. 118. Sin embargo, pese a sentirse un descastado y alardear de ello, se mostraba profundamente hinduista en su credo alimentario, como muestra su Autobiografia, Arcano Books, 2001.

87 Que vindica en El nuevo humanismo (FCE, México, 1999) una globalización que acerque los saberes y experiencias de las diversas tradiciones e intenta constantemente señalar sus puntos de contacto, más verosímiles unos que otros, todo sea dicho; por ejemplo cuando expone el sutra del loto o proporciona el ejemplo del bodhisattva como modelos estético-morales (Op. cit., pp. 24-25). En este camino hay precedentes, como Lin Yutang, cuyo libro La importancia de vivir (versión esp. Sur, Buenos Aires, 1954), ha sido olvidado, cuando es el primer precedente de este mestizaje filosófico.

88 El diseño inteligente, frente a la literalidad de Adán y Eva, tiene sus adeptos, sobremanera firmes. La evolución humana, tal como fue presentada por Huxley, ateleológica, no está admitida todavía en los grandes monoteísmos, La evolución, síntesis moderna, Losada, 1965; el propio Darwin no desdeñó introducir al Creador cuando lo vio preciso, El origen de las especies, EDAF, 1970, pp. 477 y ss. por ejemplo. La Historia Natural todavía no es, aunque resulte asombroso, una historia verdaderamente compartida. En el presente se ha hecho cierta la teoría clásica de la «doble verdad»: planetariamente se conoce la verdad de la historia natural y ésta resulta contraria al par que compatible con las diversas y divergentes narraciones religiosas del origen.

89 Cuyas obras realizan tiradas magníficas, como el caso de Morris cuyo Mono desnudo es un best seller mundial. Los documentales científicos corrientes presentan a estas figuras entrando en todos los temas y en todos a la vez, sin que sea posible separar asuntos graves de le- 
El naturalismo es el riego de nuestro tiempo. Lo avisaba Javier Muguerza hace casi veinte años. Y, de momento, tan sólo las religiones aparecen como no naturalistas, pero aún precio inabordable. Pero ies necesario el antropocentrismo para conjurarlo? Imaginemos, no es después de todo falso, que no seamos tan importantes ni necesarios como para que el mundo, ese, el externo y natural, exista; imaginemos que no está ahí por y para nosotros. Que no nos tenga como teleología. Provoca, sin duda, cierto disgusto, pero lo sospechábamos desde hace algún tiempo. Hemos digerido en tres siglos saberes capaces de descentrar a los entendimientos puros, pero, por fortuna, la carne nos sostiene sobre nuestros pies. Admitir semejante destronamiento es la condición de un humanismo que ya no es ni geocéntrico ni tampoco antropocéntrico, pero que es. Un humanismo al que se le vuelve a hacer, cada vez, la pregunta romántica, la de Nietzsche y Dostoievsky, ¿Tiene sentido en tal mundo todavía hablar de valores? Sí. Y dejo sin solucionar una duda que siempre me atenaza: Pero, ¿quién hace esa pregunta y para qué la hace?

Esos dos desahucios del centro del existir son las inteligencias basales y elementales del mundo que han cambiado en el par de últimos siglos, tanto, que hasta han tocado a la cultura compartida y la imagen popular del mundo. Son inteligencias planetarias. Quiero decir que quizá Oriente no esté muy interesado en la historia del Mediterráneo, que la pueda llegar a considerar idiolectal, pero difícilmente declinará conocer la llamada «historia natural». Ni menos las técnicas conexas. Hay un XIX que todavía consideramos poco, el de Comte y Spencer, que mantuvieron la idea de que algunos saberes modificaban la moral ${ }^{90}$; claramente no eran rousseaunianos. ¿Se pueden importar técnicas sin sus matrices conceptuales conexas, entre ellas y en lugar eminente las morales? De ahí la pregunta inevitable: ¿Han afectado estas evidencias, estas inteligencias planetarias al debate moral, religioso, político? Sin duda alguna y sería ciego no advertirlo. Pero lo han hecho de muchos modos. Han abierto el asunto del fundamento, de la pregunta romántica, y no conocemos bien todavía sus efectos.

Volver a la pregunta de si se pueden sostener valores con pretensión de universalidad en un mundo que ha cambiado sus seguridades antiguas y plurales, que eran proporcionadas por el vehículo valorativo religioso, y un que ha realizado el paso de autoconciencia de saberse pequeño y limitado, pienso que nos remite, en un grado menor y más asequible, a lo que Hare llamó en su día «universalizabilidad». Nos coloca ante valores y consensos de valor, si bien en un modo bastante restringido. Responder a esa pregunta afirmativa-

ves; no dudo de la valía de Morris o Eysenck, alguno de cuyos libros admiro, pero nada ganan perorando en programas de divulgación sobre las oficinas coreanas o la aparente incapacidad de los varones para utilizar la plancha.

90 Spencer afirma que, con el progreso técnico, las fuerzas físicas se transforman en fuerzas vitales, sociales y morales y lo hace repetidas veces en Los primeros Principios, Madrid, 1905 , pp. 191 y ss. 
mente no implica ningún raro descubrimiento, porque los valores o los propósitos de la vida no se descubren ${ }^{91}$. Desde la universalizabilidad habría valores siempre que hubiera fines compartidos y sólo como medios para alcanzar la teleología compartida. Si le añadimos como contenido de mínimos la Declaración del 48 podemos afirmar que, con pocas excepciones, ése es el límite del humanismo. No tiene otro fundamento... ni, es mi opinión, lo necesita.

Y ¿desde cuándo ocurre esta novedad? Este modo de enfrentar la cuestión, deshaciéndose de la pregunta, tiene una fecha que no puede ser eliminada, precisamente el diez de diciembre de 1948. Quienes suscribieron la Declaración sabían bien que nunca se habrían podido poner de acuerdo en su fundamento, así ellos mismos lo relatan y escriben ${ }^{92}$, pero decidieron acordar en los contenidos. Tradujeron a educación, salud, libertad de expresión, libertad de conciencia, libertad religiosa los valores básicos que ya habían sido el frontispicio de la Revolución Francesa. La igualdad y la libertad vienen dadas por los derechos individuales que constan en la Declaración y que, tras casi sesenta años, muchos estados han ubicado en sus Constituciones. La Declaración del 48 ya no es Derecho moralizante, por usar una expresión de Tierno Galván, sino positivo en bastantes estados. Pero, es verdad, es una Declaración Universal que varios no admiten, otros no respetan y algunos que se autodenominan multiculturalistas pretenden orillar.

No la admiten distintos estados del planeta, por diferentes motivos, políti$\cos$ o religiosos. No la respetan figuras intelectuales que la suponen un idiolectismo occidental, como Huntington; y la pretende orillar el multiculturalismo amparándose para ello en el superior derecho de las comunidades a la existencia, a sus rasgos, a su «diferencia». Estos son los frentes, pragmáticos y discursivos, en que el humanismo ha de presentar cara en el tiempo presente, con una invariante de fondo que citaré, porque normalmente no se hace: $e l$ tácito acuerdo en la subordinación femenina. Pero eso será asunto de la tercera de estas conferencias. Tomando ahora humildemente nuestro oficio, que no es gobernar el mundo, comenzaré por dirigirme a quienes, siervos de la palabra como nosotros, mantienen posiciones contrarias e inicio con los multiculturalistas.

\section{Multiculturalismo vs. multiculturalidad}

«Multiculturalismo» es un palabra relativamente reciente en el vocabulario político español. Sin embargo, lleva cierto tiempo funcionando en la filosofía

91 Lo expresa mejor Huxley: «Si deseamos actuar hacia un propósito para el futuro del hombre somos nosotros mismos los que debemos formular ese propósito: Los propósitos en la vida se hacen, no se encuentran», op. cit., p. 549.

92 Algunos textos seleccionados aparecen en Los derechos del hombre, Laia, Barcelona, 1973, y otros están citados o tienen su referencia bibliográfica también en Ética para un mundo global, pp. 49 y ss. 
política. El «debate del multiculturalismo» ${ }^{93}$ ha sido ya desde hace una década motivo o título de más de una reunión o congreso profesional, al igual que, adelanto, su antónimo, el «universalismo» ${ }^{94}$. En el caso español el interés ha sido en principio «doméstico». El debate ha venido en sus inicios de la mano de la propia estructura autonómica del Estado. Bastante comunidades autónomas asocian su legitimidad o su aspiración a un mayor autogobierno a la existencia en ellas de un «hecho diferencial» defendible; suelen con ello aludir a un conjunto amplio y difuso de características singulares que van desde la lengua propia, tradición anterior de autogobierno, usos peculiares de derecho consuetudinario, mitología, folclore, tradiciones, etc. Para defender ese conjunto de la tentación jacobina que siempre se le supone al Gobierno Central, muchas comunidades echaron y echan mano de la defensa de la multiculturalidad tal y como ésta ha sido realizada sobre todo por la teoría política canadiense y norteamericana en las dos últimas décadas. Adelanto que es munición demasiado pesada como para usarla en casa.

En fin, en la fillosofía política canadiense o estadounidense el multiculturalismo se ha invocado también desde diversos ámbitos y de diversas maneras para promover más finos encajes en la concepción de una democracia avanzada.

Quizá el de Canadá es el caso más claro por el medio y por sus repercusiones: Son conocidas las tensiones políticas entre las comunidades anglófona y francófona y las varias consultas ya efectuadas acerca de su separación. A fin de propiciar una dinámica particularista que, sin embargo, admita la estructura de un estado único, ambas comunidades tienden a nombrarse a sí mismas como «culturas». Pero el caso de Canadá es aún más interesante porque al lado de esta tensión a resolver, conviven en él también y forman parte de su «riqueza cultural» grupos de pobladores autóctonos, previos a las migraciones europeas que reclaman un estatuto diferenciado, así como comunidades posteriores de diverso origen que mantienen la pretensión de conservar su acervo propio de tradiciones. En el primer caso están, por ejemplo, los pueblos indígenas, que se nombran a sí mismos como las «primeras naciones»» ${ }^{95}$, cherokees con hurones, pawnis, dakotas... que se resisten, y con argu-

93 «Ninguna diferencia sin igualdad» puede bien ser el lema del multiculturalismo bien entendido. Así lo he defendido en Ética para un Mundo Global. La cuestión nos importa, porque, como europeos, no pasarán otros treinta años antes de que nuestras sociedades sean de hecho multirraciales y, no sabemos en qué medida, multiculturales. Nos es imprescindible tener un criterio y tenerlo claro. Algo que permita, por ejemplo, distinguir con nitidez entre un tabú alimentario y una mutilación indigna, un uso festivo y libre del atuendo o una imposición onerosa e intolerable de una marca de inferioridad.

94 Mucho más, desde luego, y veremos más tarde el porqué, en el exterior, pero también aquí. Basten dos ejemplos españoles: «El multiculturalismo a debate» Luis García San Miguel (director), Universidad de Alcalá de Henares, Llanes, 1996, o «Los Universalismos» Semana de Ética y Filosofía Política, Universidad de la Laguna, Amelia Valcárcel y Gabriel Bello (directores), Sta. Cruz de Tenerife, 1997.

95 «Pueblos originarios» los llama ahora Evo Morales, con una semántica más cargada, a punto de saltar la espita de una ola de indigenismo en la América hispana. 
mentos, a aceptar sin más los procedimientos de una democracia representativa; en el segundo las comunidades hindúes, asiáticas, hispanas, africanas, etc., que quieren continuar cultivando sus propios idiomas, herencias y modos de convivencia.

Con esos tres frentes tan distintos abiertos, en 1988 Canadá estableció una Ley de Multiculturalidad para «preservar y realzar el carácter multicultural del país», ley que pretende acudir a todos esos extremos. Cita la Ley a los pueblos aborígenes, las dos lenguas, francesa e inglesa, oficiales, así como a las minorías de otro origen y declara que «Es política del Gobierno de Canadá reconocer y promover el entendimiento de que el multiculturalismo refleja la diversidad racial y cultural de la sociedad canadiense y reconoce la libertad de todos los miembros de la sociedad canadiense de preservar, realzar y compartir sus patrimonios culturales». Canadá, ha de tenerse en cuenta, es uno de los escasos países que solicita al día de hoy emigrantes y cuyas prácticas de asilo son más abiertas. Está positivamente empeñado en avalar la idea de que «diversidad es riqueza» y poner freno a cualquier brote racista.

Cito el caso canadiense porque es uno de los primeros en el que el multiculturalismo pasa de ser un debate académico a convertirse en una regla de uso de la comunidad política. El multiculturalismo, en la acepción que lo toma la ley canadiense, procede de lo que he llamado «el elogio de la diferencia» ${ }^{96}$ y como tal se manifiesta en los considerandos y proemio de esta Ley ${ }^{97}$. Asume la concepción de una democracia participativa en la que «todos los individuos tengan asegurado igual trato e igual protección bajo la ley respetando y valorando su diversidad». Se refiere también a las comunidades como sujetos y objetos de protección. Evito, de momento, el caso estadounidense aunque la suposiciones de nuevo de Huntington sobre la minoría hispana y su rechazo del republicanismo apuntan por donde pueden ir desarrollándose las cosas y los argumentos ${ }^{98}$. Canadá está orgulloso de su multiculturalismo. Y quienes han provisto de argumentos a la situación, también ${ }^{99}$. Pero que sean las comunidades sujetos y objetos de protección nos lleva a otro asunto, otro aspecto, que también se encuentra, además del previo debate filosófico del multiculturalismo, debajo de ese texto legal: el comunitarismo.

96 Ética para un mundo global, op. cit., pp. 23 y ss.

97 Que cita además como fundamento declaraciones anteriores: La Convención Internacional para la eliminación de todo tipo de discriminación racial y el Pacto Internacional de Derechos Politicos y Civiles.

98 Huntington, ¿Quiénes somos? Los desafios a la identidad nacional estadounidense, Paidós, Barcelona, 2004.

99 M. Walzer, por ejemplo, en Esferas de la Justicia y en el caso de Canadá de manera sobresaliente Will Kymlicka que, cierto con muchas matizaciones, no se desprenden de la comunidad como marco de referencia. 


\section{El comunitarismo}

De nuevo nos encontramos ante otro debate en filosofía política, para que luego digan de las manos blancas, debate que surge en los años ochenta del siglo XX, y que también tiene la pretensión de mejorar y profundizar una convivencia avanzada. El asunto consiste en la vindicación de la comunidad como sujeto moral y político dentro de la estructura estatal de administración. Es un asunto simple: si el principal cauce de expresión de la democracia es solamente el voto libre y secreto de los individuos votantes, la democracia queda limitada a un procedimiento para la toma de decisiones; pero todos sabemos que una democracia, y más la democracia como ideal normativo, no se reduce a esto. Comporta también un conjunto de valores que el estado democrático tiene como trasfondo. Ahora bien, el comunitarismo afirma fundamentalmente dos cosas: que las comunidades que se integran en el estado son sujetos morales y políticos que han de encontrar vías de interlocución y participación en el estado y que el individualismo es un mal compañero mo$\mathrm{ral}$. Por la primera parte es fácil acordar en que limitar la democracia al voto cada cierto tiempo marcado para ello es, sin lugar a dudas, tergiversar lo que «democracia» significa en toda su extensión. Y, yendo al segundo argumento, la estructura simple de participación que el voto supone cierto que es individual. En opinión de los comunitaristas este hecho, sumado a un concepto prevalente de los derechos como derechos individuales, ratifica de facto una de las peores características del conjunto social y político actual, el individualismo.

El individualismo es el responsable, según los comunitaristas lo entienden, del emotivismo moral, de Goffman mismo y sus funestas secuelas: sobreimpostación del interés propio y pérdida de sentido de la acción moral humana ${ }^{100}$. Por el contrario, y a su entender, los individuos no pueden ser vistos como previos a sus comunidades de origen y adhesión en las cuales sus acciones cobran sentido y durabilidad. El individualismo es el principal disolvente del sentido de comunidad, que sin embargo ha sido y continúa siendo el único pilar capaz de marcar fines a los individuos en tanto que sujetos morales. Para contar con gente que esté dispuesta a ser moral - lo que implica necesariamente no poner el interés propio por encima de todas las cosas-, esta gente ha tenido que ser llevada a otra disposición, la obediente y altruista, dentro de su grupo de amparo y subjetivización, normalmente una comunidad, sea ella la familia, la aldea, su iglesia, su pueblo... etc.

En resumen: Si tenemos todavía sujetos capaces de ser morales es porque las comunidades los fabrican. Pero las comunidades poco pueden hacer si no son reconocidas ni ayudadas en esta función imprescindible. Por ello las co-

${ }^{100}$ El máximo expositor de este punto de vista en A. McIntyre en su conocida obra After Virtue (1981), versión esp. Tras la Virtud, Crítica, Barcelona, 1987. 
munidades no reclaman, sin más, un derecho a la diferencia fundado en una especie de narcisismo, sino que exigen ser atendidas como las fuentes privilegiadas, si no únicas, de sociabilidad moral. Hasta el momento, y quizá a causa de un universalismo mal entendido, las comunidades no se han sentido apoyadas por el Estado; por el contrario, han sido vulneradas por él y por su capacidad uniformadoa. Perfeccionar la democracia quiere decir, en el lenguaje comunitarista, prestarles voz, canales y recursos.

Vemos ahora cómo se vinculan el comunitarismo y el multiculturalismo. La suposición común es que la diferencia añade un plus de riqueza a la convivencia estatal. Pero, para poder realizar esa benéfica labor cada comunidad no debe ser obstaculizada por el propio Estado que, con prácticas ajenas a ella, la deslegitime o peor aún, la disuelva. Si el pueblo Hurón, por ejemplo, ha elegido siempre a sus jefes por medio de un consejo de ancianos que actúan inspirados por antiguos ritos, no tiene sentido imponer a los hurones el sistema de listas y voto que utiliza un ayuntamiento pequeño corriente. Los hurones obedecen a sus jefes porque advierten en ellos una marca de sacralidad que viene directamente de su modo de ser seleccionados y tal marca desaparecería de serles conferida la jefatura por el sistema democrático corriente. Así pues - por ejemplo-, si la existencia del pueblo hurón supone una riqueza a la que la comunidad estatal canadiense no quiere ni debe renunciar, ello implica que los hurones han de ser eximidos de los procedimientos democráticos corrientes. Ellos son distintos, desean seguir siendo distintos y todos queremos que sean distintos y lo que son; por lo tanto, han de poder mantener rasgos diferenciales aunque ello suponga modos comunitarios y políticos arcaicos o poco compatibles con ciertos derechos individuales.

\section{El asunto del tamaño}

En el caso de la «Ley de multiculturalidad» canadiense los casos a que se ha querido atender, aunque disímiles, están claros. Y con independencia de cuál sea nuestro juicio sobre el asunto, se ha buscado un criterio abstracto, la «riqueza cultural» para enfocar la cuestión. Un caso bastante similar se produce en otro de los ámbitos del pensamiento político donde multiculturalismo y comunitarismo han tenido gran presencia y desarrollo, los Estados Unidos. Es cierto que el debate académico no ha producido todavía resultados contantes políticos, pero está en vías de hacerlo.

No tenemos en este caso dos comunidades fuertes en cierta tensión ${ }^{101}$. Los pueblos indígenas tampoco son tan fuertes y variados como sus vecinos

101 Como es el caso de anglófonos y francófonos, pero hay que decir que «todavía». La comunidad hispana, si su ritmo demográfico y de autoconciencia continúa, podría presentar en breve tiempo un escenario parecido al canadiense, si bien no por distribución geográfica, sino por presencia y trabajo. Sin embargo, no parece que los Estados vayan a tomar la vía canadiense, por lo menos en lo que vamos viendo en este tiempo. 
del norte. Pero están las diversas comunidades europeas, africanas y asiáticas de origen, muchas de las cuales insisten cada vez con mayor fuerza en la interlocución directa con el Estado. De hecho los llamados «líderes de las comunidades» son personas suficientemente significativas como para que se las convoque o se les den a juzgar los programas electorales. Debemos además pensar que en el caso de la democracia americana este modo de actuar ha sido relativamente corriente. Tocqueville, en su temprana descripción de su funcionamiento, nos informa del gran protagonismo de los «grupos de interés» 102 en la vida política que contempla. Todos estos grupos buscaban y buscan interlocución con las Instituciones públicas e introducir en la agenda común sus objetivos. Las comunidades son, sin ninguna duda, fuertes grupos de interés. Ahora bien, la novedad reside en que en los Estados Unidos del siglo XIX la mayor parte de las comunidades que buscaban de este modo sus fines eran las iglesias y grupos similares. Por su propia naturaleza tenían que aliar sus objetivos con la idea de tolerancia religiosa. Ahora es otro asunto.

Los grupos comunitarios de interés han suplido, puesto que son grupos de encuadre que suponen un origen común y una voluntad de conservar sus diferencias, la idea de tolerancia religiosa por la de riqueza multicultural. Han avanzado un paso, que consideran decisivo, el elogio de la diferencia, sobre los planteamientos anteriores. Y no ahora un elogio de la diferencia simple, sino moralmente motivado, el que plantean los principales pensadores comunitaristas, como McIntyre, Sandel o Walzer. Sea mediante la recuperación de la ética aristotélica o por otros procedimientos, la convicción de fondo es que la democracia y la pertenencia tienen que hacer ajustes entre sí. Muchos intuyen que no son del todo compatibles. La dinámica entre particularismo y universalismo se muestra compleja.

102 «Los americanos de todas las edades, de todas las condiciones, de todas las mentalidades, se unen constantemente. No solamente tienen asociaciones comerciales e industriales, sino que también las tienen de milo otras especies: religiosas, morales, intelectuales, serias fútiles, muy generales y muy particulares, inmensas y muy pequeñas. Los americanos se asocian para dar fiestas, fundar seminarios, edificar albergues, levantar iglesias, distribuir libros enviar misioneros a las antípodas... si se trata en fin de poner en evidencia una verdad o de desarrollar un sentimiento... se asocian... he encontrado en América clases de asociaciones de las que confieso que ni siquiera tenía idea y frecuentemente he admirado el arte infinito con que los habitantes de los Estados Unidos conseguían fijar un objetivo común a los esfuerzos de y un gran número de hombres y hacerles marchar hacia él libremente... Así, el país más democrático de la tierra resulta ser entre todos aquel en que los hombres han perfeccionado más en nuestros días el arte de perseguir en común el objeto se sus deseos comunes y donde han aplicado esta nueva ciencia a mayor número de propósitos; ¿ha sido esto el resultado de un accidente o será que existe, en efecto, una relación entre las asociaciones y la igualdad?». La democracia en América, Aguilar, 1989, Tomo II, p. 147. Así, en efecto, es la democracia. 


\section{Multiculturalidad, migraciones y comunidades: Europa}

En Europa no desconocemos tampoco esta dinámica, pero, desde luego, ni nuestras políticas ni nuestras costumbres asociativas han llegado tan lejos... todavía. América es, en casi su totalidad, un continente formado por emigrantes. Ha sido colonizado en oleadas en las que, quienes primero llegaban, difícilmente podían justificar ante los más recientes un primitivo y previo ius solis. Ése no parece ser nuestro caso. Pero, dejando por el momento esto a parte, lo único previo entonces sólo podía consistir en la forma general de la convivencia política, cuyas reglas y procedimientos generales habían de asumirse. El problema ahora es que el comunitarismo, aliado con el multiculturalismo, pone en duda alguno de esos supuestos de fondo.

Lo más significativo es que, para la mejor existencia de la comunidad, no sólo los rasgos del individualismo han de ser desterrados de su cultura moral común, sino que, me temo, han de serlo también los ejercicios plenos de algunos derechos individuales. Y adelanto que esto reza sobre todo para los derechos individuales de las mujeres.

Hablar en abstracto de la comunidad compromete poco con la forma efectiva en que una comunidad se produce y reproduce y además borra las diferencias «de género» que en ella vigen. Una comunidad no es sólo el intento de mantener la memoria del origen común y la voluntad actual de diferencia; es, en los hechos, también y ante todo un conjunto de prácticas entre las cuales son especialmente relevantes las de género. Las mujeres son el «como siempre», y tomo la expresión de Aristófanes ${ }^{103}$, de todas las comunidades, real o ficticio. Una comunidad supone costumbres, creencias a veces religiosas, rituales, normas familiares, matrimoniales, vestimentarias, de uso de espacios, de tiempos, tabúes alimentarios, relaciones de los grupos de edad y, en lugar principal, grupos de género. Pero sobre este asunto versará la tercera de estas conferencias.

\section{Un multiculturalismo no doméstico}

Casi todo el mundo que está pendiente del proceso de globalización y los flujos migratorios que genera sabe que el aspecto de la Vieja Europa no diferirá dentro de poco tiempo, veinte años a lo sumo, del de Manhattan: gentes de todos los colores, atuendos y tipos. Me pregunto si nos estamos preparando para ello, si estamos utilizando la pedagogía moral y política adecuada para afrontarlo. Si este multiculturalismo importado y, hasta ahora usado sólo domésticamente, nos servirá.

Este acaso es inevitable. Llegar a Europa es sencillo, comparado con lugares más inaccesibles. El Mediterráneo no se puede vallar, como sucede con la

103 Que la da en El gobierno de las mujeres. 
frontera entre México y los Estados Unidos, que así y todo, tampoco creo que resulte. Las fronteras con los antiguos países del Este son también permeables. Las gentes se embarcan cada día arriesgando su vida y a veces perdiéndola. Enfrentamos el reto de poder asimilarlas poniéndonos todos bajo una ley común ${ }^{104} \mathrm{o}$ sufrir tensiones inauditas que pueden hacer peligrar nuestras formas políticas y nuestros modos de vida. Conocemos imperios que hicieron murallas, pero recordamos la sentencia de Heráclito, la ley son las murallas.

\section{Ley y sentimiento}

Al fin, lo que se enumera como derechos, como ley, es razón, fría razón incluso, y sabemos que el humanismo ilustrado abrió el otro gran continente, el sentimiento. En la última década le hemos cambiado el nombre y solemos darle el de inteligencia emocional ${ }^{105}$. Algunos europeos podemos instar a nuestros conciudadanos a que recuerden que también fuimos pobres en tierra extrajera y hace muy poco; pero no parece que ese recuerdo sea capaz de enfrentar otro sentimiento muy poderoso, cada vez más presente, la xenofobia. Jugaremos en medio de grandes tensiones, me temo, en el futuro inmediato; ya las estamos teniendo, con las posiciones tomadas por los partidos tribunicios y nuestras últimas experiencias electorales afectadas por la paradoja de Condorcet 106; necesitamos ideas claras, no meramente estratégicas.

La vieja Europa no es, en principio, un lugar que carezca de un ius solis previo y haya tenido que pactar principios reguladores universales con comunidades celosas de su propia identidad. Como mucho, y en algunos Estados solamente, comunidades que se declaran previas a la propia existencia del Estado-nación han luchado por un cierto grado de autonomía política. Pero, y no precisamente de modo pacífico, en su mayor parte los estados de la vieja Europa se libraron de sus propias comunidades distintas o disidentes por medio de asimilaciones forzosas, expulsiones e incluso genocidio. Europa, e excepción de su pluralidad de lenguas y sus estados del todo independientes, es relativamente homogénea, tanto étnica como religiosamente ${ }^{107}$.

104 Doblemente común, universal y al alcance de todos, según el uso que de esta expresión hace M. Delmas-Marty, Pour un droit comun, Seuil, 1994.

105 Nombre que han intentado, y con éxito, tanto Goleman como Damasio, el primero con su best seller internacional bajo el mismo título (1995), Kairós, 1996, seguido por El punto ciego, Plaza y Janés, 1997; y el segundo con su En busca de Spinoza (2003), Crítica, 2005.

106 Entiendo por partidos tribunicios aquellos que viven de canalizar demanda, sin particular base propia o fiel, que es sustituida normalmente por la colocación en un terreno previo, lugares donde tradicionalmente obtienen voto. De ahí que, donde tienen arraigo, sean fáciles de desarraigar por otras opciones igualmente tribunicias. En cuanto a la paradoja de Condorcet, él mismo la enunció y la hemos visto producirse ante nuestra vista: «prefiero $a$ a $b$ y $b$ a $c$, pero no $a$ a $c$ ». La preferencia no es transitiva. En las democracias sobran efectos electorales de esta paradoja.

107 Por ello la sorpresa que producía que a la guerra que fragmentó Yugoslavia se la tratara insistentemente de «guerra étnica»; ni con la mejor vista se podían apreciar diferencias ra- 
La importación del «debate de la multiculturalidad» ha afectado sobre todo a las alas más progresistas del pensamiento político europeo, por un lado para dotar de legitimidad a las escasas naciones sin estado ${ }^{108}$ y por otro para completar la idea primitiva de tolerancia religiosa con una tolerancia cultural que se enfoca hacia los todavía moderados en número grupos de emigrantes. Algunas de las naciones europeas han sido en el no tan lejano pasado, imperios. Los procesos de descolonización han llevado hacia las antiguas metrópolis oleadas de emigración que dependen para su homogeneidad con la población metropolitana, del tipo colonial prevalente en el siglo colonizador. Así la colonización española, premoderna, que fue territorial y religiosa, como la más temprana de ellas y lo mismo en el caso de Portugal, recibe principalmente un reflujo emigrante que es homogéneo cultural y religiosamente con la población peninsular, aunque no exista uniformidad racial.

Los casos de Gran Bretaña y Holanda son distintos: al haber sido su colonización sobre todo comercial y como mucho administrativa, el reflujo contiene diferencias religiosas y culturales notables. Y éste es el mismo caso de Francia, cuyo protectorado sobre el Magreb da ahora como resultado la presencia de un número considerable de emigrantes musulmanes. Los grupos asiáticos son numéricamente y de momento poco significativos. Y a este reflujo se está añadiendo en los últimos tiempos emigración ilegal africana y otra bastante fuerte de los antiguos países del Este. Pero, incluso contados todos estos grupos, Europa dista bastante de ser un mosaico cultural. Con todo, ¿es probable que está abocada a convertirse en él?

La combinación del atractivo que nuestra sociedad rica produce en las zonas deprimidas de África y América con la bajísima tasa de fecundidad de nuestro continente llevaría a cualquier lego a vislumbrar el horizonte a medio plazo: lo que ahora se presenta como reflujo de los imperios coloniales, se extenderá cada vez más y dará como resultado una sociedad europea tan diversa como pueda ser la estadounidense. De ahí que el pensamiento progresista, siempre más ocupado por las cuestiones de horizonte que el conservador, se afane en incorporar los términos del debate multiculturalista y realizar con ellos los debidos ajustes. Pero no podemos esperar que encajen por sí solos.

Las demandas, por justas que fueren, de unos y otros, no son asintóticas, sino que existen aquí y ahora. La tolerancia no es ninguna panacea y plantea bastantes problemas prácticos ${ }^{109}$. Desde luego a una fuerte rama del progre-

ciales entre los contendientes, pero nadie quería o quizá no podía usar la expresión adecuada, «guerra religiosa»; aún el fenómeno comenzaba.

108 Que pocas quedaron tras la disolución del Imperio Otomano, el romano germánico y la aplicación bastante puntillosa de los principios Wilson; pero tenemos los casos evidentes españoles, las comunidades religiosas en Irlanda o el terrible disolverse de Yugoslavia.

109 De entre las últimas reflexiones sobre el papel de la tolerancia en las sociedades complejas, M. Walzer Tratado sobre la tolerancia, Barcelona, 1998, porque, al fin, hasta los comunitaristas se han visto llevados a revisar sus posiciones. 
sismo, el feminismo, se los plantea. Y pensemos que el feminismo, aunque sigue teniendo su núcleo principal de emergencia y propuesta en el progresismo, es, de alguna manera, un rasgo general y común del mundo en que vivimos. Se está convirtiendo en una regla de uso por mor de sucesivas victorias de la agenda feminista en los últimos tres siglos. La democracia lo ha incorporado y los individuos, mal que bien, lo asumen. Al menos hasta cierto punto ${ }^{110}$.

El multiculturalismo no doméstico ha de hilar muy fino cuando enfrenta a las identidades preilustradas o a las identidades reactivas, porque la mayor parte del peso de tales identidades recae sobre la mengua de los derechos individuales, en particular, sobre los derechos y libertades de las mujeres. Y no basta con asegurar que las prácticas, cualesquiera, se legitiman por la voluntad individual, que puede estar captada o menos aún, por el fin, la solidez del grupo. De los tres modelos convivenciales desarrollados hasta el momento en Europa ninguno parece estar dando buenos resultados: ni lo «trabajadores invitados» de el salto industrial alemán, ni la convivencia multicultural británica ni el republicanismo francés están logrando de momento bajar el perfil fundamentalista o resolver el problema de la ciudadanía de los llegados.

\section{Ciudadanía global: los segundos no-universalistas}

Uno de los pensadores importantes del momento presente, Huntington, sostiene las posturas menos proclives al universalismo que conozco y dice hacerlo en exclusiva por las evidencias que proporciona la sociología, sin que el multiculturalismo o el comunitarismo le hayan tocado. Saca sus datos: no nos dicen que se esté consolidando una interlingua mundial ni una religión con el mismo alcance; bien al contrario, se manifiesta un retorno cada vez mayor las identidades más étnicas y previas. Lo universal no aparece por ninguna parte, o peor, no existe; lo que sucede es que llamamos así a lo nuestro: «La idea de civilización universal encuentra poco apoyo en otras civilizaciones. Los no occidentales ven como occidental lo que Occidente ve como universal» ${ }^{111}$. Recuerda la impresión, citada por Daisaku Ikeda, sacada por un oriental tras ver el Museo del Prado. Su respuesta a cómo lo había encontrado fue: «muy cristiano». Estamos tan inmersos en nuestros valores que los creemos universales. Los demás no lo comparten.

$\mathrm{Su}$ tesis es que un grupo humano, y la humanidad es sólo un conjunto de conjuntos, se define por lo que no es. Así, le cito, «A medida que el incremento de las comunicaciones, el comercio y los viajes multiplican las interacciones

110 Hasta este, notable, de que un varón o mujer de escasas convicciones feministas de nuestro modo de vida occidental, casi con seguridad las tiene más asumidas que cualquier varón o mujer de los mundos que nos preceden o que nos son contemporáneos, por avanzados que pudieran ser en sus planteamientos individuales.

111 El choque de civilizaciones (1996), Paidós, Barcelona, 1997, p. 77. 
entre civilizaciones, la gente va concediendo cada vez más importancia a su identidad desde el punto de vista de la civilización. Dos europeos, uno alemán y otro francés, en mutua interacción se reconocerán como alemán y francés. Dos europeos, uno alemán y otro francés y dos árabes, uno saudí y otro egipcio, en interacción se definirán como europeos y árabes» ${ }^{112}$. Admito y sin ironía de ninguna clase que Huntington sabe dos cosas que hay que saber en el momento actual, historia y demografía. Su argumento puede fácilmente proseguirse: si cada identidad necesita de otra, su contraste, de no haber marcianos, la humanidad jamás tendrá una identidad común. No tiene contra quién tenerla. $\mathrm{Su}$ argumento, a tomar en serio, se parece mucho, muchísimo a uno que el joven Hegel empleó en sus inéditos sobre el cristianismo: una comunidad universal de amor es imposible, porque una comunidad existe si hay otra frente a ella ${ }^{113}$. Y quizá ese parecido nos sirva para despejar, en lo que sea posible, tan fuerte cuestión: comienzan a existir grandes segmentos compartidos de humanidad sabida, con independencia del retorno a las identidades, que Huntington sostiene que se realiza sobre todo por la vía religiosa. La comunidad política no es una comunidad de amor, ni puede serlo, sino de justicia. De ahí que los mínimos de justicia se hagan cada vez más importantes.

$\mathrm{Y}$ en este punto conviene volver, bastante humildemente, a la pregunta ¿cuáles son las posibilidades de la ciudadanía global? Si en un continente como el nuestro, probado por decenas de conflictos y de capacidad de invención técnica, moral, social y política demostrada, hemos de reconocer que nos encontramos a menudo en situación de bloqueo ${ }^{114}$, no es fácil suponer que, no ya la civilización, sino la ciudadanía global esté al alcance de la mano. Estamos partiendo de la Declaración del 48 y es, como fundamento, todo lo que tenemos. Esa tabla de mínimos de respeto y dignidad que establece y los principios humanistas que la informan son por ahora ambas cosas ${ }^{115}$ : el fundamento y el contraste, lo que se comparte y lo que permite distinguir unas posiciones políticas de otras. Es la enumeración de contenidos de lo que ahora damos por aceptado y compartidos. No lo consideramos idiolectal, sino una consecución similar o superior a cualquiera de nuestras innovaciones científicas y técnicas. Es la mayor consecución de los tiempos que corren: el sacarnos del estatuto naturalista del mal.

Una vez terminada la guerra fría vamos avanzando en su apoyo con pequeños aunque significativos pasos: la creación del Tribunal Penal Interna-

112 Ibidem, p. 78.

113 En «El espíritu del cristianismo y su destino», en Escritos de Juventud, edición de J.M. Ripalda, FCE, 1978.

114 Por no llamar de modo más brutal a las penúltimas elecciones francesas, los asesinatos políticos selectivos por motivos religiosos, el bloqueo del texto constitucional... y evitamos hablar, como otros lo hacen, de decadencia.

115 Como ocurría con la indistinción que Schopenhauer impugnó entre principio y fundamento en su agudo ensayo Los dos problemas fundamentales de la ética. 
cional, algunas aplicaciones extraterritoriales del derecho ${ }^{116}$, intervenciones de paz, nuevos motivos de asilo y refugio; pero hemos de reconocer que la distancia con el fin confesado es enorme, nos supera. Para los problemas planetarios sólo tenemos tratados, nunca universalmente firmados y para la ciudadanía global los Dikeos del 48 en este estatuto todavía a medio camino. También nuestras instituciones internacionales son endebles. Necesitamos un resurgir del humanismo y en dos vertientes, como internacionalismo y como sentido moral de la democracia.

\section{Ciudadanía compasiva}

En ocasiones la democracia no sólo nos enseña el qué, sino también el cómo ${ }^{117}$. El sentido moral de la democracia, no sólo su tabla de derechos y deberes, será necesario también. Convendrá una ciudadanía educada no sólo en la defensa de sus derechos sino también en la ayuda. Y el metro de justicia que la democracia enseña no incluye, por ahora, lo que es supernumerario, lo voluntario.

Hace años Victoria Camps aseguraba que necesitaríamos la caridad además de la justicia si queríamos cumplir con lo que la ética bien formada exige. Hay dos lugares, que se van haciendo comunes, en el discurso experto sobre la democracia: Uno es el consejo de «evitar la prédica humanitaria», asunto grave porque es muy difícil matizar en estos puntos. El segundo consiste en querer separar nítidamente lo que libremente hacemos por los demás, por ejemplo el voluntariado, de la caridad. Pero lo cierto es que la democracia necesita imperiosamente la prédica humanista y que el voluntariado está supuesto y amparado por ella porque es precisamente exceso caritativo ${ }^{118}$. El sentido moral de la democracia justamente supone lo uno y lo otro. Es y debe ser parte de la pedagogía cívica, la educación para la ciudadanía ${ }^{119}$. Sentirse

116 Los procesos en Francia por abusos sexuales contra menores en Tailandia, por ejemplo, son inicios e indicios de aplicación extraterritorial del derecho, lo que no sería posible sin los cincuenta años transcurridos de costumbre y uso de la Declaración del 48.

117 Esto es especialmente patente en el área a la que llamamos voluntariado «El destino del voluntariado está en la recuperación de la cultura de la sensibilidad, que valora la gratuidad y la donación, esa energía que invade todo el universo y hace que los seres existamos y vivamos unos por otros, en los otros y para los otros», Joaquín García Roca, «Retos y Perspectivas del voluntariado», Actas del II Congreso Andaluz del Voluntariado, Sevilla, 2004.

118 Ello no impide tener en cuenta cuantas salvedades al peligro de que el Estado se escaquee mediante el voluntariado de campos que debe cubrir o trabajo, justo, que se le encomienda hacer, suscribo plenamente el análisis de Javier de Lucas en «entre el altruismo y el deber», Actas del Congreso Andaluz del Voluntariado, Sevilla, 2003.

119 Recordemos el asombro que a nosotros mismos nos provocó ver lo que sucedió con la catástrofe ecológica del «Prestige». La ciudadanía es esa capacidad de movilización, tan individualista y sin embargo tan solidaria que a las gentes formadas en la moral democrática se nos aparece en momentos singulares. 
ciudadana y ciudadano implica la ayuda, la cooperación, dentro y fuera de las fronteras nacionales. La voluntaria o el voluntario, menos abundante, no regala tiempo, o no tiempo solamente, sino tiempo lleno de compasión. La compasión es el fundamento sentimental de la ética. Si no te sabes poner en el lugar de otro o no sientes que le estimas sufriente no puedes hacer algo, siquiera sea de modo mecánico. Una vez ese espíritu debió rozarte. En alguna parte se ha aprendido. Y las prédicas bárbaras y antihumanistas lo minan. Existen aún en el planeta demasiados lugares crueles.

A la mayoría de los pueblos se les educaba en la falta de compasión, hasta límites insospechados. Había que alejarla, porque se la confunde fácilmente con el miedo ${ }^{120}$. Ya los grandes grecolatinos indagaban en lo que hace valeroso. Y no es la crueldad ${ }^{121}$. El mundo ha sido largo tiempo tortuosamente humano: ha sacado el mal por el bien y viceversa: ha escrito recto sobre renglones torcidos. Ha vivido una historia sacrificial ${ }^{122}$. Y en ella la compasión ha sido obliterada para permitir, sin embargo, la catarsis. Podemos entristecernos por Jesús o por Alí, pero hemos de ser adustos con el prójimo sufriente porque no está claro que sea prójimo y porque implicarse es malo.

Educarse en la contención ha sido educarse de todos modos mejor que cuando se hacía directamente en la crueldad. Lo que ahora consideramos patológico ha constituido la norma de algunas civilizaciones, de sus diversiones y espectáculos. Y debe decirse, sin miedo a la risotada del energúmeno, que conviene volverse blando ${ }^{123}$. Que la compasión debe ser educada y puesta al servicio de buenos fines. Precisamente porque está más allá de la justicia.

Las actuales migraciones, los continuos paseos que nos damos por la frágil piel de la tierra, el saber de este mundo nuestro pequeño y limitado, la seguridad de nuestra continuidad con la naturaleza no pueden dejar de producir efectos. Creo que las migraciones construyen ciudadanía y hasta el turismo lo hace cuando nos pone ante el otro que, desvestido de exotismo, interroga nuestra común humanidad. Hasta las religiones, cuando se vuelven éticas - y esto sólo ha sucedido tras procesos de Ilustración-, confluyen hacia el humanismo. Desde luego, admito que puede haber muchos otras salidas, pero sólo ésta parece la buena. Una ética global para una ciudadanía global.

120 Sostiene acertadamente Bodei que hay en realidad un nudo indiscernible de sentimentalidad en origen, un continuo que el lenguaje ordena; la democracia es ordenadora cabal que separa compasión y miedo; vid. R. Bodei, Una geometría de las pasiones, Muchnik, 1995.

121 Es precisamente, siguiendo la mejor razón aristotélica, superar razonablemente el miedo; por así decir, la valentía no se posee, se alcanza: «primero haces lo más calmadamente que puedas eso que te da miedo y, como precipitado, te entra la valentía».

122 Para cada emergencia, un mal previo. Ha de producirse la Shoah para que exista Israel y éste inicia otra cadena causal con su propia suma de males. Y así continuadamente.

${ }^{123}$ El indebolimento de Vattimo acude especialmente a este punto, porque llama así a lo que, desde un punto de vista más tradicional, se nombraría simplemente como decadencia; pero de nuevo el lenguaje pone orden. 


\section{El feminismo es un humanismo, pero informado}

En 1936 Clara Campoamor corregía las galeradas de su libro Mi pecado mortal. Lo había escrito para explicar y explicarse: tras luchar denodadamente y conseguir los derechos políticos de las españolas, el sufragio universal, sabe que lo pagará; conoce que su carrera política ha terminado, pero no está dispuesta a dejar sus convicciones indefensas. Escribe: «Digamos que la definición de feminista, con la que el vulgo... pretende malévolamente indicar algo extravagante... indica la realización plena de la mujer en todas sus posibilidades, por lo que debiera llamarse humanismo».

En los recientes funerales de Betty Friedan, de las muchas personas o parientes que realizaron el elogio fúnebre, bastantes transmitieron sus frecuentes afirmaciones: «El feminismo es un humanismo, es parte esencial del humanismo». Elijo dos manifestaciones de dos feministas emblemáticas del siglo XX, separadas por épocas y distancias culturales, sufragista una, sesentaiochista otra, española Campoamor y anglosajona judía Friedan, empero ambas acordes. En tanto que feministas, ninguna renegaba del término, sino que querían presentarlo en su plena dimensión. Dar su contenido y su teleología clavándolo en el mapa al que pertenece. Y quizá también señalar al hacerlo que el feminismo es nada más ni menos que la vindicación de la humanidad de las mujeres ¿Pero, es que hay que vindicar algo tan evidente?

Puede que sí; todos los grupos humanos han sabido, además de que la humanidad termina donde lo hace la tribu, que las mujeres son «diferentes» $\mathrm{Y}$ esto, dentro del antiguo paradigma, no quiere decir nada bueno. Ahora el que no es diferente no es nadie. Hay nadies, incluso, que dejan de serlo volviéndose diferentes. A esos surte de vocabulario una rama singular de la filosofía política que ya ha sido citada, el multiculturalismo. El multiculturalismo, debo repetirlo, ha querido ser la plantilla de desarrollo de la democracia avanzada. No es fácil porque no afina lo suficiente; permite, por ejemplo, defender con argumentos ilustrados prácticas pre-ilustradas. Como instrumental teórico no discrimina lo bastante. Sin embargo debo ahora realizar una distinción que creo precisa y de hondo calado; es de Celia Amorós: La multiculturalidad, esto es, que pertenecemos a ámbitos sociales, normativos e imaginarios diferentes, es un hecho y planetariamente innegable. El planeta es multicultural, lo sabemos desde las primeras exploraciones. Estuvo y está lleno de identidades humanas diversas. Nadie en su sano juicio lo negará. Pero el multiculturalismo es otra cosa: es una toma de postura sobre ese hecho. Procede del elogio de la diferencia. Y como toma de postura es bastante problemática. Porque el asunto de la diferencia es que hay una, la femenina, que las recorre todas, de ahí que nos resulte, a algunas, tan sospechosa. Porque en el juego de las identidades conviene saber bien el terreno que se pisa. 


\section{Multiculturalismo y feminismo}

Me temo que en el campo político, y por mucho que Franklin introdujera esa expresión en la Declaración de Independencia de los Estados, no hay casi nada autoevidente. Evidencia es como llegamos a llamar a las innovaciones políticas y morales cuando han alcanzado el consenso y la fuerza suficientes. Pero, por la propia naturaleza de las innovaciones que plantea, el feminismo tiene su nicho de acogida más asentado dentro de las tradiciones progresistas y es ahí donde recientemente también el multiculturalismo ha buscado su lugar. ¿Disputan por el espacio o por el fondo del asunto?

Afirmé en la conferencia anterior que la tolerancia no es ninguna panacea y plantea bastantes problemas prácticos ${ }^{124}$. Desde luego a este fuerte filón del pensamiento de la democracia, el feminismo, se los plantea. Lo más significativo del multiculturalismo es que, para la mejor existencia de la comunidad, no sólo los rasgos del individualismo han de ser desterrados de su cultura moral común, sino que, me temo, han de serlo también los ejercicios plenos de algunos derechos individuales. Y adelanto que esto reza sobre todo para los derechos individuales de las mujeres.

Hablar en abstracto de la comunidad compromete poco con la forma efectiva en que una comunidad se produce y reproduce y además borra las diferencias «de género» que en ella vigen. Una comunidad no es sólo el intento de mantener la memoria del origen común y la voluntad actual de diferencia; es, en los hechos, también y ante todo un conjunto de prácticas entre las cuales son especialmente relevantes las de género. Las mujeres, por parafrasear a Aristófanes de nuevo, son el «como siempre» de todas las comunidades, real o imaginado. Una comunidad supone costumbres, creencias, a veces religiosas, rituales, normas familiares, matrimoniales, vestimentarias, de uso de espacios, de tiempos, tabúes alimentarios, relaciones de los grupos de edad y, en lugar principal, grupos de género. Creo que ya se ha dicho.

En realidad este enorme sustrato normativo fue detectado tempranamente por la filosofía. Primero lo señaló Montesquieu, al marcar la diferencia entre leyes y costumbres y al oponer las normas explícitas legales y religiosas a las normas que cada sociedad tenía por más seguras ${ }^{125}$. Poco más tarde, a princi-

124 De entre las últimas reflexiones sobre el papel de la tolerancia en las sociedades complejas, ya se ha citado a M. Walzer, Tratado sobre la tolerancia. De allí extraigo este apunte «entre los temas que más dividen a todas las sociedades contemporáneas se encuentran los relacionados con las formas de organización familiar, los diversos papeles de género y la conducta sexual... el dominio masculino prácticamente universal ha establecido los límites de lo que se podía discutir sobre esta cuestión (y sobre quién podía participar en la discusión). Hoy en día esos límites se ponen en cuestión debido a la amplia aceptación de las ideas relativas a la igualdad y a los derechos humanos», op. cit., pp. 72-73.

125 En El Espíritu de las Leyes; las costumbres son previas a las leyes y su forma de enunciación es diferente. Pero también leyes penales, religiosas y morales explícitas son distintas de las normas que una sociedad sabe realmente vigentes. Por ejemplo, escribe, en las Socieda- 
pios del siglo XIX, Hegel, uno de los mejores lectores de Montesquieu, en la Fenomenología del Espíritu le dio nombre a ese monto previo normativo: eticidad. Filósofos y comentaristas posteriores han alabado la perspicacia hegeliana o han usado su distinción moralidad/eticidad para diversos fines. Pero pocos han reflexionado en algo evidente: que Hegel hace correlatar en directo la eticidad con la división sexual de la normativa social.

Varones y mujeres no están separados por una mera dimorfia natural espontánea, biológica, diríamos utilizando un término anacrónico en el contexto hegeliano pero que permite comprender lo que Hegel afirma. Ser lo uno o lo otro dice, es una realidad espiritual; y con ello quiere afirmar que son conjuntos normativos los que separan a los sexos. Los varones viven para el espacio público y las mujeres para el privado. Ellos para el Estado y ellas para la familia. Ellos son, por la naturaleza de su espacio simbólico, móviles, y ellas, por lo mismo, inertes. Unos se arriesgan y otras conservan. Sin tener que recurrir a caracterizaciones de la eticidad tan abstractas como suelen serlo las hegelianas - la eticidad llega a ser definida como «lo sabido y querido»-, podemos reconocerla en todos los aspectos normativos tan asumidos por todos que no necesitan por lo común ser explícitos. Varones y mujeres se visten de modo diferente y tienen también reglas diferentes del vestir honesto. Se expresan y han de expresarse de modo diferente. Asumen disposiciones corporales y posturas diferentes. Ningún grupo humano - ninguna comunidad en los términos en que venimos hablando-, ha visto con buenos ojos un proceso de aglutinación e indiferencia de estas normas basales. Las relaciones en que estén los sexos y que cada comunidad considere óptimas pueden variar; pero lo que no varía es que la existencia de la comunidad siempre ha implicado normativas diferentes en función del sexo ${ }^{126}$. Creo que conviene seguir echando mano de Hegel porque su análisis es magistral: los varones, dice, son lo diferenciado y las mujeres lo indiferenciado. Ellas son un continuo y ellos una reunión de individuos. Y recuerdo esto porque traerlo al caso permitirá saber algo sobre de qué se habla cuando se habla de individualismo.

El individualismo, ese azote que los comunitaristas quieren prevenir y combatir, responsable del deshacerse del tejido moral y social moderno, les está supuesto por su normativa a los varones y prohibido completamente a las mujeres. En otros términos: que nadie puede ser individuo si no es también un tanto individualista, pero que quien tiene por eticidad el deber de mantener

des monárquicas, marcadas por la virtud prevalente del honor, dará igual que las leyes del Estado y la Religión prohíban el duelo: este se realizará porque todo varón educado o no sabe que su honor depende de llegar a mantenerlo por medio de él. Así existirán siempre dos morales: la que se enseña en la educación formal, que se acata pero no se cumple, y la que se aprende cuando se sale del colegio, que resulta ser la que no admite violaciones.

$126 \mathrm{La}$ obra definitiva en que esta verdad se expresa con la mayor exactitud y finura es Masculino y Femenino de la antropóloga M. Mead, de 1949, notablemente el mismo año de publicación de El segundo sexo de S. de Beauvoir. 
lo homogéneo no puede en modo alguno permitírselo. El relativo individualismo de los unos asegura la capacidad grupal de amoldarse a cambiantes circunstancias, readaptar la tradición y triunfar, asegura la pervivencia del grupo en último término. Sin embargo sería nefasto en quienes cargan con el deber de mantener la inercia.

Algunos de los más significativos comunitaristas, McIntyre por ejemplo, hacen tabla rasa de todos estos más que importantes aspectos, pero enseñan sus verdaderas convicciones cuando realizan el juicio a la Modernidad. Llamamos así al gran período de innovación y cultura que comenzó en Europa una vez cerradas las Guerras de Religión por la Paz de Westfalia en 1648. Casi todo el repertorio de nuestras ideas se gestó en el pensamiento barroco y tomó carne durante la época que le siguió, la Ilustración. Ahí es donde McIntyre señala el comienzo de la disolución del sentido moral y el ascenso rampante del individualismo. Su solución es conocida: como vivimos en un período de barbarie del que no somos conscientes, algunos pocos, inteligentes, conscientes y avisados, deben reconstruir pequeñas comunidades, no de otro modo que como lo hizo San Benito cuando el Imperio Romano desapareció ${ }^{127}$. La catástrofe iniciada por la Modernidad ha sido tan grave que casi nadie se da cuenta de ella. Peor aún, en vez de percatarnos, consideramos que son logros las más evidentes marcas de la disolución generalizada que vivimos. El lenguaje moral no funciona, la gente cree tener derechos individuales, pero los individuos están lanzados a una lucha cínica de todos contra todos... ¿Tendrán estos juicios generales algo que ver con la disolución de la eticidad?

\section{El cuidado y las reglas}

Capturemos otro hilo argumental que viene aparentemente desde otras posiciones. En la filosofía moral contemporánea y también en el feminismo ha tenido presencia en los mismos momentos del arreciar comunitarista una distinción bien conocida: ética de las normas y ética del cuidado, los deberes abstractos contra los deberes concretos. Gilligan, en un best seller internacional ${ }^{128}$, fue la autora que la consagró. El origen estaba en un estudio previo de otro autor, Kohlberg. Éste encontró diferencias significativas entre la forma en que varones y mujeres parecían abordar los mandatos morales. Los unos solían fijarse en la noción de derechos individuales y en los criterios universales de justicia, eran capaces de buscar tales criterios incluso saliéndose para ello de los corrientes en sus grupos de encuadre; las otras no solían pensar en tales términos, sino que más bien estaban situadas en un marco emocional ca-

\footnotetext{
127 Tiene su gracia, porque son comunidades que, con tal modelo, el de San Benito, no podrían reproducirse.

128 In a different voice (1982), nueva edición con un nuevo y largo prefacio en 1993, Harvard U. P., Mass. y London.
} 
racterizado por «un fuerte sentido de ser responsables del mundo», pero, subrayo, del mundo próximo: una misma, la familia, la gente que se conoce... y tenían dificultades para traducir las abstracciones morales a deberes concretos ${ }^{129}$. Kohlberg sacó de todo ello la chusca idea de que las mujeres nunca alcanzaban el desarrollo moral completo; y éste fue el detonante de la obra de Gilligan, quien, por otra parte, había trabajado con él.

Ella, por el contrario, sostuvo la existencia de una ética diferencial entre mujeres y varones; el nombre que ha venido recibiendo tal ética es «ética del cuidado». El argumento de Gilligan es que lo que Kohlberg supone estadios des desarrollo moral humano son sólo los rasgos de la moral masculina, marcada por las abstracciones, mientras que las mujeres tendrían un sentido acusado de la proximidad moral. Al ser ambos, Kohlberg y Gilligan, psicólogos y operar desde su disciplina, en la que tan difícil parece ser introducir el sentido histórico e incluso algunos de los datos de la antropología, ambos suponen que sus caracterizaciones son, sin más, intemporales, sin radicación territorial y verdaderas por tanto «en cualquiera de los mundos posibles». Se adhieren sin cautelas al esencialismo ${ }^{130}$. Pero, considerada su polémica desde otro ángulo, lo cierto es que sus caracterizaciones casan perfectamente con lo esperable si los rasgos de la individualidad se toleran o no en función del género.

Hegel, también en la Fenomenología, no sólo señalaba esta escisión en el seno de la eticidad, sino que suponía la existencia muy posterior de un nuevo modo moral que habría dependido del proceso general de autoconciencia humana, la moralität, a la que propiamente llamaba moral. Su formación habría sido tan tardía como la época ilustrada, aunque habría tenido formas y precedentes en las escuelas helenísticas, la religión cristiana antigua y la Reforma. En verdad y entonces asimilaba su hallazgo a la formulación del imperativo categórico kantiano: una moral a la vez individual y universalista que abolía a la tradición y también a las religiones como fuentes normativas primarias.

Tal moral, decidió Hegel más tarde ${ }^{131}$, era «abstracta». Y, cierto que se parece bastante a la que Gilligan llama «moral masculina». Esto es así porque Kohlberg se inspira directamente en un kantiano, Habermas, a la hora de diseñar sus «estadios» del desarrollo moral. Pero lo que ella mantiene que es una moral diferente, femenina, «del cuidado», es toda la larga serie de deberes inargumentados asociados además con fuertes sentimientos de responsabilidad y culpa que caracteriza a las morales previas a la libertad de conciencia. Sostengo, por lo tanto, que no se está hablando de una «moral femenina», 1981.

129 Kohlberg L., The Philosophy of moral development, Harper and Row, San Francisco,

${ }^{130}$ Lo que hace especialmente incomprensible que Habermas tomara por bueno a Kohlberg y menos, desde sus posiciones, a las consecuencias geopolíticas de la aplicación de sus caracterizaciones, según las cuales sólo los europeos varones llegan al estadio superior de la moral. Quizás es que el otro nombre de Habermas es «también».

131 En la Filosofía del Derecho, catorce años posterior a la Fenomenología. 
sino de la moral que es forzado a mantener todo aquel que es dependiente, sea mujer, sirviente, esclavo, vasallo o inferior ${ }^{132}$. Concluir que tal conglomerado se tiene por naturaleza me parece simplemente una monstruosidad carente de sentido social e histórico.

Recuperando ahora el tema de las comunidades para conjugarlo con éste del cuidado, he afirmado que en todas ellas el estatuto diferencial de varones y mujeres se mantiene; siempre hay una eticidad que norma, sobre todo, al colectivo femenino, llámese cuidado, decencia, abnegación o por nombres todavía más sonoros. Y que cualquier comunidad, aunque es vigilante del excesivo individualismo de sus miembros, se fija especialmente en que sean las mujeres las que no se desmanden. Esto es tan conocido que no necesita ejemplos y explica que las mujeres se sientan «hipernormadas» no sólo por la existencia de una doble moral, sino por tener que cumplir con el doble o el triple de deberes.

Evidentemente, hasta las sociedades más individualistas mantienen cierta tasa, bastante alta, de eticidad. Y todos la reconocemos cuando se producen lo que llamaré «situaciones de contraste». Por individualista que sea la sociedad en que vivimos, cuando una persona mayor cae enferma, nunca se busca con la mirada a sus hijos varones, sino a sus hijas, hermanas o nueras. Del mismo modo que no se las busca si de lo que se trata es de ejercer presión o violencia sobre extraños; entonces se mira inquisitivamente a los varones. Los papeles, por así decirlo, siguen asignados. Y existen, además, regresos significativos y queridos a esa eticidad grupal en fechas señaladas: los ritos de paso, por ejemplo, o ciertas festividades, suelen volver a separar los espacios entre los varones y las mujeres, incluso en los grupos cuyos miembros son acusadamente individualistas por inoculación social.

Seguimos, y lo sabemos, teniendo reglas diferenciales, algunas de las cuales estamos dispuestos a asumir, al menos de modo esporádico aunque significativo, pero también es cierto que nos hemos deshecho de un gran conglomerado anterior de ellas. Y en este trance, o medio camino, nos cogen tanto el comunitarismo como la multiculturalidad. En realidad las polémicas que venimos ventilando se reducen en Europa a la vigencia de la semiótica. Intentaré explicarme.

\section{Ética y estética}

Los signos, y especialmente los vestimentarios, puede que en el momento presente y en las sociedades occidentales no estén demasiado cargados, pero lo estuvieron también en este suelo hasta el pasado más reciente. El vestido ha sido jerárquico y genérico. Todavía yo tuve la oportunidad, si se puede ha-

132 J. Mitchell, pensadora clásica de la Tercera Ola feminista, tematizó este asunto en Psicoanálisis y feminismo (1974), Anagrama, sin año de edición. 
blar de ello en estos términos, de escuchar en los años setenta un sermón dominical en que el preste glosó la apropiación de los pantalones para la indumentaria femenina, - que nosotras estábamos realizando-, acudiendo al versículo de la Biblia que reza «No se vista el varón con ropas de mujer ni la mujer con ropas de varón porque esto es abominación a los ojos de Dios». Y eso me lleva al punto del porqué de aquellas modas.

Desde los felices veinte del pasado siglo, la vestimenta femenina sufrió transformaciones asombrosas. Éstas, no sólo correlataban con un nuevo estatuto, más aún, se daban a la vez, sino que, mantendré, lo hacían explícito sobre todo para aquellas que seguían las modas sin necesidad de seguir las ideas que les estaban dando aliento. Quiero decir que al lado de una rebelión ética siempre se produce una rebelión estética y que su orden no es mecánico. En los veinte, al lado de la tendencia a la androginia muy poco seguida, el vestido diferencial se mantuvo, pero el femenino comenzó a expresarse como «libre». Muchas mujeres, que no habían expresado adhesión por la agenda del sufragismo, comenzaron entonces a introyectar sus nuevas posiciones por medio de la aceptación calurosa del nuevo vestido. Y no olvidemos que la moda es una fenómeno masivamente igualador. Y, por si poco fuera, tampoco cabe olvidar que para muchas gentes que por posición social no están nunca en la órbita cercana de los grupos innovadores, la rebelión estética es su manera inconsciente se sumarse a unas causas que desconocen o incluso podrían rechazar.

Si por ejemplo estudiamos la historia y progresión de las vindicaciones feministas en el último franquismo, podemos fijarnos en los grupos agitadores, su cantidad, su ubicación geográfica y política, sus miembros, sus nombres o sus coberturas legales. Pero si queremos saber la verdadera capacidad de penetración del nuevo trasfondo de ideas, no nos queda mas remedio que acudir a los números masivos expresados por la moda. Bastantes mujeres de aquellas décadas no serán capaces de describir la situación legal y moral existente y tampoco recordarán haberse opuesto frontalmente a ella, pero guardarán memoria de su propia Bildung en la historia personal de sus leves rebeliones estéticas y afirmarán que fueron valerosas al ponerse pantalones, fumar en público, abandonar los cardados o no llevar medias, del mismo modo que las mujeres tras la Primera Guerra hacían alarde de cortarse el pelo, ir de manga corta, evitar el corsé o gastar zapato bajo.

«Yo siempre fui muy rompedora» es lo que suelen decir de sí mismas.

Pero es muy distinto portar un signo ética o estéticamente. Un signo se porta estéticamente cuando su anterior carga ética está desactivada. Desplegaré un poco la afirmación anterior de que el vestido ha sido jerárquico y genérico. En todas las culturas humanas habidas varones y mujeres no se indistinguen, ni siquiera lo hacen en nuestra sociedad indiferenciada. Y, de vez en cuando, en ocasiones especiales, el vestido jerárquico y genérico reaparecen. Sucede en lo que he llamado «regresos significativos». La obligación de 
«vestirse», para ciertas ocasiones de relieve, quiere decir vestirse adecuadamente, según el rango y el sexo de cada uno. Por lo general las novias no se casan de pantalones. Y también por lo común los varones no se visten con prendas femeninas. El estándar universalizado siempre es el superior, el varonil. Los varones no se ha feminizado, sino que las mujeres han adquirido el derecho a llevar, sin esfuerzos morales, prendas antes masculinas: blaziers, americanas, pantalones, calzado, sombreros, corbatas.. etc. En las ocasiones especiales el vestido genérico regresa: cada sexo vuelve por sus fueros en los trajes de gala o en la portación de los antiguos trajes étnicos en sus fechas.

Para las mujeres el frente de batalla contra sus derechos individuales han sido los moralistas, y casi nunca las leyes explícitas; los moralistas, situados en la eticidad, en la defensa de la moral y las buenas costumbres, realizan el ataque cuando la eticidad se tambalea; con sólo esto, suelen cumplir su propósito. Hablo de nuestro suelo europeo y de hace bien poco.

\section{Universalismo, relativismo y feminismo}

El feminismo es un universalismo de raíz ilustrada que ha dirimido siempre su agenda política con la ayuda de las declaraciones universales. Lo que nace como una polémica sobre la igualdad de los dos sexos, remitida exclusivamente a su igual capacidad y dignidad, se transforma en una lucha por los derechos individuales y políticos cuando éstos son por primera vez enunciados. Ha funcionado por una lógica deductiva irrefutable, pero sus conquistas no se deben precisamente a la fuerza en sí misma de la lógica deductiva, sino a su sistemática puesta en ejercicio por medio de grupos de interés que tuvieron que afrontar un grave rechazo moral y social.

El feminismo es, por descontado y por su raíz ilustrada, un universalismo y un adherente a la idea de derechos individuales. Por tales rasgos, resulta disolvente para la eticidad y, es más, ha contribuido como nadie a disolverla. Ha venido marcando una agenda en los últimos tres siglos que, a medida que se ha ido cumpliendo, ha sacado a las mujeres de la eticidad y ha convertido en opresión política lo que era sin más admitido anteriormente como buenas costumbres. Esto ha sucedido en el plano práctico, pero no quiero ocultar que en el sustrato teórico del feminismo y en las argumentaciones que usa y ha tenido que usar para desmontar tramos completos de prácticas y valores, el feminismo se ha servido de fuentes muy próximas a las del multiculturalismo. Me refiero al relativismo cultural. Es un precedente del multiculturalismo que se presenta en el siglo XX. Y en parte se debe al propio desarrollo de la antropología como discurso experto.

La idea de que todas las sociedades, incluidas aquellas que han alcanzado un alto desarrollo institucional y las que no han pasado de ser pequeños grupos tribales son más o menos equivalentes, es el mismo núcleo del relativismo. La hemos rastreado en la primera de estas conferencias. Pero el relativis- 
mo, con independencia de ese exagerado aserto, ha sido extremadamente útil al feminismo. El relativismo permite, justamente, relativizar. Y cuando una situación, y fuerte como era la femenina con la eticidad en todo su esplendor, que se presenta como absoluta, sin contraejemplos e inmune a las argumentaciones, ha de ser desfondada, el relativismo y su compañero el comparativismo son y han sido una excelente ayuda.

Contra la idea de que los rasgos que una cultura atribuye a lo femenino son «naturales» basta con invocar a otra que los sitúe de otra manera, y los ejemplos abundan. Y no menos servicio ha hecho al feminismo la antropología cultural, de suyo proclive al relativismo, cuando ha desmontado el mismo concepto de «cosas que son como son por naturaleza» ${ }^{133}$. De hecho, una de las herramientas conceptuales que el feminismo utiliza a menudo, incluso con demasía, el concepto de «género», tiene también este origen próximo. Digamos que en estos casos el relativismo ha presentado su faz más amable, pero desde luego posee otra bastante peor: Si se extrema - si todo vale lo mismo-, cualquier principio moral o político queda abrogado.

Normalmente el feminismo ha usado la cara amble del relativismo. Pero el multiculturalismo puede y suele usar la otra. Cada cosa es, simplemente un rasgo de cultura, defendible en su contexto, de modo que igual es y da que en Occidente las mujeres elijan a sus parejas sin coerciones familiares que el que en otras culturas se venda a las esposas. O allá se van la ablación y el peircing, por poner ejemplos que pueden oírse o leerse ${ }^{134}$. Y visto ello, el feminismo ha solido usar con cautela el relativismo y normalmente no lo ha llevado al extremo.

Pero, allí donde el debate de la multiculturalidad ha alcanzado mayor desarrollo, Estados Unidos y Canadá, se asiste también a la inclusión de la teoría feminista no dentro de la teoría política, sino en el seno de los «estudios culturales» o los «estudios de género». Todos ellos están marcados, en efecto, por la impronta de cierto grado de relativismo cultural. Y, cierto, encontraremos que esa cercanía produce algunos discursos académicos de «feminismo multicultural» cuando menos complicados de asumir. Que también tienen sus respuestas dentro de su propia área cultural, todo hay que decirlo. Autoras como I.M. Young o Ann Ferguson ${ }^{135}$ coquetean con el multiculturalismo y el feminismo diferencialista y otras como Okin o BenHabib ${ }^{136}$ mantienen posiciones más templadas o universalistas. De todos modos el resultado es, de

133 Por ejemplo, el los espléndidos trabajos de M. Douglas Símbolos naturales, Pureza y peligro o Cómo piensan las instituciones.

134 Este último nada menos que en G. Greer, La mujer completa, pp. 149 y ss.

135 Young, I. M. La justicia y la política de la diferencia, Cátedra, 2000; Ferguson, A. Sexual democracy: women, opresión and revolution, Westwiew, 1991.

136 Moller Okin, S. Women in western political thougth, PUP, 1991; BenHabib, S. Situating the self: Gender, community and postmodernism in contemporary ethics, Routledge, 1992, y Teoría feminista y teoría critica, Alfons el Magnanim, 1990. 
momento, variable. De ahí que otros autores, que sobrevuelan la polémica y se pueden permitir los juicios apodícticos, por ejemplo $\mathrm{H}$. Bloom, identifiquen sin más los espacios y fines del feminismo y el multiculturalismo, los identifiquen, y los hagan, cierto que en compañía de otros, responsables de la decadencia cultural, moral y política de Occidente ${ }^{137}$.

\section{Feminismo y tolerancia}

Como ya he dicho, del hecho de que todas las vindicaciones del progresismo se autoconciban como asintóticas, esto es, capaces de ser puestas todas vigentes a la vez en el horizonte utópico, no se sigue que tales vindicaciones sean realmente compatibles entre sí. En el horizonte utópico cada progresista desea que se llegue a instaurar una sociedad igualitaria, participativa, pacífica, ecológica, libre y planificada; pero en el aquí y el ahora, y ya escribió Hegel que siempre existe sólo aquí y ahora, muchas de estas demandas o son incompatibles entre sí o necesitan severos ajustes. La demanda de respetar la diferencia cultural, por ejemplo, nos puede llevar a pasar por la violación de demasiados derechos individuales duramente conseguidos en los dos últimos siglos. Son, sobre todo, los derechos individuales de las mujeres aquellos cuyo estatuto es más vacilante. Y de los primeros, elementales e inalienables, no de los concebidos como derechos derivados. El derecho a la libertad puede ser interrumpido por varias prácticas matrimoniales o paternales de algunos grupos. El derecho a la integridad física pasa por los mismos avatares. Y otro tanto sucede con derechos más recientes, pero no menos importantes, como la salud, la educación, la libre circulación, etc. Sin contar con el extraño caso del derecho, todavía no reconocido, a la imagen.

Pero el estatuto de las mujeres ya no pertenece al orden privado, sino al público. Como escribe Walzer, «la línea teórica y práctica entre lo tolerable y lo intolerable es muy probable que se dispute y se trace aquí en torno a lo que llamaré, por abreviar, cuestiones de género» ${ }^{138}$. El «género», prosigue el mismo autor, «se consideraba como un problema esencialmente interno». Pero ya no lo es, desde 1948 no lo es, aunque haya que haber recordado, y en convenciones internacionales, que los derechos de las mujeres son derechos humanos ${ }^{139}$. En todo el planeta, mujeres de los grupos más diversos se mueven a favor de sus libertades lo que suele implicar ir, de manera frontal o más lateral, contra las prácticas heredadas. Y ello produce tensiones grupales.

Podemos imaginar, y todavía volveré sobre ello, que las civilizaciones chocan por sus maneras divergentes de ver el mundo y que luchan por los re-

137 El canon occidental, Anagrama, Barcelona, 1994, especialmente pp. 525 y ss. Bloom habla de una «escuela del resentimiento» de la que hace formar parte al feminismo.

138 Op. cit., p. 73.

139 La ocasión y sede más importante, nada menos que por la Asamblea General en la CEDAW, 1979. 
cursos energéticos. Aunque ambas fueran ciertas, la primera implica una severa fractura que es muy operativa y de la que el feminismo no puede ser eliminado.

Cuando el feminismo ha afirmado que, pese a que en la Declaración del 48 se hace expresa mención de abolir toda forma de discriminación en función del sexo, las mujeres aún no tienen reconocidos la plenitud de sus derechos individuales, no se equivoca en absoluto. Lo prueban todas las cifras que nos son conocidas. Y no hace falta para ello ni siquiera salirse de las sociedades occidentales que son, hoy por hoy, aquéllas en que la condición de las mujeres ha experimentado mejoras más sensibles. Con la familia como principal mecanismo de encuadre de las mujeres, sometidas a una eticidad diferencial en honor de la decencia grupal, aceptando y reproduciendo prácticas de minoramiento y exclusión y todo ello avalado por las instancias religiosas y en bastantes ocasiones las políticas, la mayor parte de las mujeres del planeta simplemente no ha adquirido todavía el estatuto de individuos de pleno derecho.

La ciudadanía global exige un manejo prudente de la virtud de la tolerancia, pero no sólo por el riesgo de tolerar lo intolerable o hacer el ridículo de varios modos ${ }^{140}$, sino porque la tolerancia no puede, así lo haya afirmado el propio Rawls, ponerse por encima de la justicia ${ }^{141}$. El papel que las mujeres juegan en los grupos humanos correlata de modo efectivo con la libertad y la igualdad que haya fluyendo en el conjunto social. Lo afirmó Montesquieu, lo repitió Condorcet, que la libertad de las mujeres era la medida de la libertad que existía en un lugar o en un país. Pero, sobre esto, el feminismo ha avanzado algo. Sabe que la subordinación de las mujeres es la invariante, pero sabe además cómo y para qué se maneja. La única hipótesis es que, en sociedades no igualitarias, en sociedades del antiguo régimen, es la sumisión de las mujeres lo que asegura la igualdad de los varones, por lo tanto habrá más sumisión cuanta menos igualdad efectiva haya para repartir. Los tipos sociales más rígidos extremarán las formas de la sumisión femenina para asegurar la relativa igualdad de los varones: todas las mujeres les serán, o inferiores $u$ ocultadas, para cementar la adhesión y no despertar la envidia. Las «sociedades de encierro femenino» evitarán la mostración de aristocracias duales, porque la virilidad común es lo que debe quedar a salvo. Todas las sociedades temen la envidia. Se desactiva con la mucha distancia, pero también con una fuerte identidad compartida. La identidad viril evita pensar en el despotismo en tiempos en que su crédito es cada día más bajo. Hay estados en este planeta que en vez de repartir bienestar reparten «hombría». La naturaleza no se ha

140 Por ejemplo recibiendo una ministra del Estado español, a un ayatolá, dentro de España (en el territorio internacional del aeropuerto) cubierta con un ridículo velito. Si el clérigo no puede ver mujeres no veladas, puede él mismo ponerse gafas muy oscuras.

141 Rawls, en The law of peoples, 1993, versión española en Isegoría, «El derecho de gentes», n. ${ }^{\circ} 16$, mayo 1997. 
hecho cultura sin gastos. La libertad y los cuerpos de las mujeres han pagado un gran monto del proceso de hominización. Las condenas bíblicas siguen dando la regla general: Parirás con dolor y estarás sometida al varón. La antropología, la cultural por ejemplo, tiene este discurso ya bien identificado ${ }^{142}$. Pero estas seguridades han jugado en el pasado. Tras los procesos de ilustración y la revolución industrial que les es paralela, esas seguridades basales se pierden.

La primera consecuencia es la desestabilización de los valores compartidos, por lo que se pueden esperar bastantes tensiones. La comparecencia del individualismo femenino no es deseable para el grupo. El feminismo altera el horizonte de valor al simplemente apropiarse la norma masculina. Normalmente, para entendernos, sólo parece que se la apropia: en realidad lo que hace es construir una más universal, tras diversos tanteos, que acaba siendo aceptada ${ }^{143}$. La identidad previa quedará alterada, pero se habrá logrado una nueva homeostasis. Las mujeres, en las sociedades occidentales y durante los últimos tres siglos ${ }^{144}$ hemos ido perdiendo virtudes peculiares, aretai, que las llamaban los griegos, y eso ha implicado un descenso continuado del monto de eticidad presente, por lo tanto un incremento paralelo de la Moralität necesaria para sostener el conjunto; de ahí que en la actualidad casi todos los deberes sean y deban ser argumentados, hasta el punto de que hayamos convertido a la propia ética en el procedimiento, la argumentación. Esto es radicalmente nuevo y extraño. La moral grupal, ya lo explica a la perfección McIntyre, nunca ha sido discursiva ni universalista; ni sus actores individuos. El grupo ha sido el señor.

\section{Las mujeres y las identidades}

Hay gran cantidad de varones a los que desestabiliza tanto la libertad femenina, que prefieren la tiranía antes que el temido desorden moral. Lo que las mujeres puedan hacer con su libertad es peligroso, haram, porque son el sexo sobre el que se ha depositado la decencia. De ellas dependen la autoestima y la identidad del grupo.

Y por ello ocurre que las mujeres y el cómo deban comportarse forman parte esencial de las identidades reactivas. Llamo así a las identidades que se crean como efecto del rechazo a la integración, por ejemplo, el caso de varios fundamentalismos islámicos en territorio europeo. Sin querer olvidar el peso

142 Françoise Heritier, Masculin/Feminin I y II; existe traducción del primero, Masculino/femenino, el pensamiento de la diferencia, Barcelona, Ariel, 1997; y sobre idéntico asunto De la Violence I y II, Heritier Ed. y Directora, Odile Jacob, París, 2005.

143 Miyares, A. Democracia Feminista, Cátedra, 2003, pp. 161 y ss.

$144 \mathrm{O}$ en un período mayor, si aceptamos la tesis de Duby, según la cual la especificidad europea es la libertad femenina, cuyo origen habría de buscarse en la Baja Edad Media, Historia de las Mujeres, vol. 2, Taurus, 2000. 
de otras variables, como la propaganda salafista o wahabí y quien la financia, o la importación selectiva de imanes fundamentalistas, lo que aparece es el intento de control del grupo de los pares, los varones hermanos, sobre las mujeres propias, porque precisamente están dejando de ser «propias» e incluso «apropiadas». Casar por fuerza asegura que el grupo no se abrirá al matrimonio exogámico; para ello ha de mantenerse la prohibición mayor de la inclinación propia o el enamoramiento. La exogamia acaba con el grupo. Mejor castigar muy cruelmente la pérdida de la virginidad que tener que acudir al remedio cuando ya no lo haya. Mejor el velo, que es un signo aunque haya quien quiera olvidarlo, que la desaparición. La identidad del grupo va cargada sobre los hombros de sus mujeres, estén ellas de acuerdo o no. Cierto que algunas pueden estar de acuerdo. Muchos esclavos lloraron y se resistieron a ser liberados. Las situaciones individuales siempre son singulares y a veces extrañas; el individuo juega en el terreno justamente de la negociación de la valía individual, el elegir entre cola de león o cabeza de ratón; por eso la libertad individual para avalar tales prácticas es una razón tan débil ${ }^{145}$.

El feminismo, Pepito Grillo de la democracia, como frecuentemente lo llama Celia Amorós, como vindicación y como teoría de la democracia no excluyente, universal, ha tenido ya que recordarle sus fundamentos a ésta casi desde su origen; en verdad, viene haciéndolo de modo sistemático. Su énfasis casi nunca está en los contenidos, sino en el grado de universalidad. Ahora lo hace en la nueva situación de contraste que presenta la multiculturalidad, dentro del Estado y también en el proceso de globalización. «No sin las mujeres» ${ }^{146}$ se llama ahora su aporte formal esencial.

El programa de máximos del feminismo se enunció muy tempranamente «el salir las mujeres de una perpetua y no querida minoría de edad», pero ello ha implicado el conocimiento cada vez más exacto del sistema de poder que vige entre los sexos, el patriarcado, que pasa de ser paisaje moral corriente a sistema de dominación difícil de justificar. Allá donde se fragiliza las mujeres adquieren los rasgos de la individualidad, abandonan la Sittlichkeit y dejan de representar la identidad del grupo. Es nuevo individualismo correlata de un modo característico con la caída del pautaje diferencial de lo honesto en función de género. Las mujeres no reivindican el derecho al mal, lo ponen por obra, con los riegos que asumen por ello. Pero al ponerlo, lo imponen; si se cruza socialmente la línea de la honestidad, entonces todo el sistema normativo se resiente e incluso aparece una cierta dosis de anomia: cuando la invariante se mueve, el edificio se resiente. La libertad, por ejemplo de opción sexual o amorosa dimana como práctica directamente de las libertades de las

145 Leo con asombro que una mujer conversa al islam, con un hijo, se ha hecho reconstruir iijel himen!!! Como «un detalle de amor» hacia su nuevo marido. La realidad siempre supera a la ficción.

146 Este título emblemático puso Soledad Gallego a uno de sus magistrales artículos dedicado a Afganistán, en el diario El País. 
mujeres en el momento presente. También algunos debates como el de la prostitución. La libertad de las mujeres ha introducido altas dosis de inseguridad en la eticidad heredada, esto es, en el patriarcado, que es su otro nombre.

La Modernidad abrió el debate de la tradición y desde Descartes el pasado dejó de ser asumido como un todo; en otros términos, las identidades comenzaron a quebrarse. Y el feminismo fue una muy contundente maza, de ahí lo poco simpático que siempre ha resultado a los moralistas, que le han devuelto los mazazos multiplicados.

Es cierto que la Modernidad no hace nada de esto sin costos y de perfecto acuerdo; está por estudiarse la profunda relación entre la libertad de las mujeres y la tensión política, o si se quiere, está mal estudiado todo el fenómeno porque se ha hecho ignorando este aspecto basal. Bueno, no es éste ahora el caso. Por eso, porque la Modernidad es un proceso y no precisamente pacífico, porque no es ninguna identidad, por eso es tan absurdo asumir que el feminismo sea un «emic» occidental. Así lo enfocan las identidades preilustradas a fin de deflactar una buena parte de su atractivo entre sus propias mujeres. Ser feminista es ser traidora. Y además cada quien, máximamente los clérigos, están calificados para decidir en qué consiste ser feminista, que no suelen ni proferir el nombre, encubriéndolo bajo el término «familia», privado, o «modas procedentes del extranjero», estética ${ }^{147}$. La defensa de la tradición, que conocemos bien en nuestros lares ${ }^{148}$, implica casi siempre autarquía moral. La tradición señala un grueso cúmulo de seguridades que ni quieren perderse porque amenazan directamente a la pervivencia de la comunidad; la transforman en una totalidad atomizada en individualidades cargando cada una con su libertad; cambian las reglas del juego patriarcal. Fátima Mernissi se preguntaba en los noventa ${ }^{149}$ por qué la cuestión sobre la modernización en el islam acaba siempre convirtiéndose en la cuestión sobre las libertades de las mujeres; la respuesta, que creo que no pedía, es obvia: porque son lo mismo.

\section{Patriarcado, moral y política}

Occidente no es una cultura más, posición que sólo se puede tomar por exceso de liberalismo o por ignorancia de la facilidad de las comunicaciones. En un caso, puesto que Robinson sigue estando solo, no quiere compartir con nadie sus valores, sino sólo comerciar y seguir su ruta; lo que hagan las gentes exóticas no es de nuestra incumbencia. Allá ellos. Y menos aún es de nuestra incumbencia lo que hagan con ellas, porque son suyas; este estado de cosas pue-

147 No me resisto a recordar que el feminismo sufragista era denostado en la Alemania bismarckiana como un intento venido de Francia para debilitar a la patria.

148 Es la única ventaja de haber nacido, como lo hizo mi generación de mujeres españolas, en las coordenadas espirituales el siglo XIII.

149 Mernissi, F., El miedo a la Modernidad, Eds. del Oriente y del Mediterráneo, 1992. 
de mantenerse si el patriarcado es asumido como lo que se tiene en común, como la humanidad que es común. Porque esa reconoce en el otro la misma capacidad de dirigir su dominio, aceptado por todos, como mejor haya parecido en cada pueblo. Allá las encierran, acá salen demasiado, pero la autoridad del otro es reconocida en esa esfera suya. No hay conflicto. Ahora, evolucionada la Modernidad y activo el frente feminista, autoconsciente, Robinson ya no es lo que era. Y, además, el otro ya no se contenta con vender buenamente sus materias primas o sus riquezas exóticas, sino que se nos planta dentro de nuestras fronteras ¿Cómo mantener sobre él la mirada exotizante?

El patriarcado es un sistema de poder que ya no se comparte tanto como antaño, sin llegar a la chusca afirmación de que ha muerto ${ }^{150}$, porque tenemos el empirismo asumido. Su línea fuerte es la división entre público y privado, con una frontera nítida, el varón soberano en su casa y las mujeres excluidas de la esfera del pacto. Mal podrían ocuparla si son el fundamento de lo pactado. Y lo pactado es la ley, la legitimidad, la herencia, el respeto, lo decoroso. El patriarcado, escribe Longman ${ }^{151}$, no es un ordenamiento especialmente agradable para los varones; al fin es un orden que tiene sus exigencias y para que exista hay que mantenerlo porque no se produce ni se reproduce solo. Implica un varón proveedor, reproducirse según un orden legítimo, cuidar de la prole, el castigo del amor homófilo en nuestra variedad y, añado, la defensa de la virilidad del otro y su capacidad de ponerla en ejercicio. Cuando este tejido normativo se deshilacha, añade, la natalidad se derrumba, así que caeremos en manos de los que lo mantengan, porque les apoya la fuerza del número: nuestras cunas están vacías y las suyas no ${ }^{152}$. De modo que, por la evidencia de esa explicación que hace de lo que normalmente llamamos historia sólo una parte de la demografía, feminismo, libertad individual y democracia son autodestructivas.

No sé si es tan grave, pero sí conozco que, cada vez que capas no expertas han llegado a detentar el poder de élites duales más antiguas, por lo común las posiciones de las mujeres se resienten; los recién llegados aplican normalmente sus estándares de honestidad, es más, los ponen como ejemplo; así nos lo enseña la historia, que hasta yo comprendo que algo reza con la demografía. En ese caso, atención, porque el momento actual nos pone frente a uno de esas situaciones y nos pone globalmente. No parece buena táctica ante ella predicar la falsa tolerancia multiculturalista o diferir la realización los foros internacionales de población o mujer, como se viene haciendo.

La humanidad que tenemos en común ya no es viril. La natalidad que tenemos rompe las solidaridades de la hombría. El individuo es epiceno. Este

150 Afirmación clásica del grupo conocido por el nombre de la Librería de Milán, muy contundentemente refutada por Celia Amorós en Tiempo de feminismo, Cátedra, 1997, y también en La gran diferencia y sus pequeñas consecuencias, Cátedra, 2005.

151 Longman, Ph., «El retorno del patriarcado», en Foreing Policy, febrero 2006.

152 Longman, Ph., The empty cradle, B. Books, N.Y., 2004. 
panorama ¿es tan optimista? Según Huntington, sí; esto es lo que piensan, pensamos, lo que él llama la gente Davos; ni que decir tiene que no le concede universalidad, que en su caso quiere decir número, suficiente ${ }^{153}$. La universalidad del número no aparece planetariamente en su opinión por parte alguna, ni en la difusión de las técnicas y el consumo, ni menos en lo que vengo llamando ideas basales. En opinión de Huntington lo que él llama «cultura subyacente» permanece intocada. Pero es que la libertad de las mujeres precisamente opera en ese nivel. ¿Cómo mantener la Sittlichkeit heredada cuando un número masivo de mujeres accede a la formación media? Está demostrado que esa variable cambia todas las sociedades en que ocurre. Y ahora es casi global.

La Modernidad se abre paso desgastando la cultura subyacente y reemplazando la tradición automática por la tradición deliberada. Ya nos lo enseñó Burke cuando tuvo que acuñar el nuevo concepto de tradición, autoconsciente, de la Modernidad. La tradición dejaba de ser automática, se desgajaba del monto de la superstición y se volvía patrimonio. Nuestra reivindicación de la tradición es tradicionalista porque no es espontánea. La aparición de tradicionalismos en áreas planetarias que no los tenían indica hasta qué punto las verdaderas tradiciones han sido socavadas. Nuestra tradición, sistemáticamente, convierte las prácticas en ritos ${ }^{154}$.

En la propia historia de Occidente el fundamentalismo nos es bien conocido, pero no siempre termina como en sus inicios pretende. El humanismo renacentista lo tuvo, como antítesis en la Reforma, pero, a la postre, la Reforma llevó a libertades antes no imaginadas y para mucha más gente, no sólo para las escasas élites; por lo tanto, el humanismo ha dado varias vueltas antes de arribar a nuestro presente realizando torsiones que no debemos olvidar.

El feminismo es un humanismo que no ha descuidado ni descuida los datos de antropología, que, es más, supone una antropología no androcéntrica y no antropocéntrica, que sabe de sí y de sus límites. Que entiende qué tipo de proceso es la Modernidad, por lo tanto que distingue bien cuando habla como teoría del conocimiento, filosofía de la historia, antropología o agenda política. En su nivel teórico explicativo, alimentado por muchas fuentes, es muy rico y presenta además variables que hacen entender cosas que sin él o no se perciben o no se entienden. Pero, no se limita a entender, sino que siempre

153 Escribe: «La expresión "civilización universal” se puede referir a los supuestos, valores y doctrinas que comparte actualmente mucha gente en la civilización occidental y algunas personas en otras civilizaciones. A esto se le podría llamar la cultura Davos. Cada año, aproximadamente un millar de hombres de negocios, banqueros, funcionarios estatales, intelectuales y periodistas de decenas de países se reúnen en Davos... casi todas estas personas tienen titulación universitaria. Pero ¿cuánta gente en todo el mundo comparte dicha cultura?, menos de un uno por ciento de la población mundial», El choque de civilizaciones, pp. 66-67.

154 Tomo prácticas en el sentido que usa la expresión McIntyre en Tras la virtud; esto es, un conjunto de conductas, de teleología compartida, que anudan la vida social, presididas por valores-virtudes. 
implica transformar. En buena parte del mundo las mujeres tienen ya ciudadanía y donde esto no ocurre, la rebeldía está presente. Nuestros enfrentamientos civilizatorios no son por los ritos, tampoco por los recursos o no solamente por ellos; son por el modelo general de humanidad. Y la libertad de las mujeres es el cuño del modelo universal y universalizable. Rebeldes, Solas o Juntas, las mujeres comenzamos a ser Ciudadanas del Mundo. 